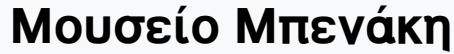

Tóp. 7 (2007)

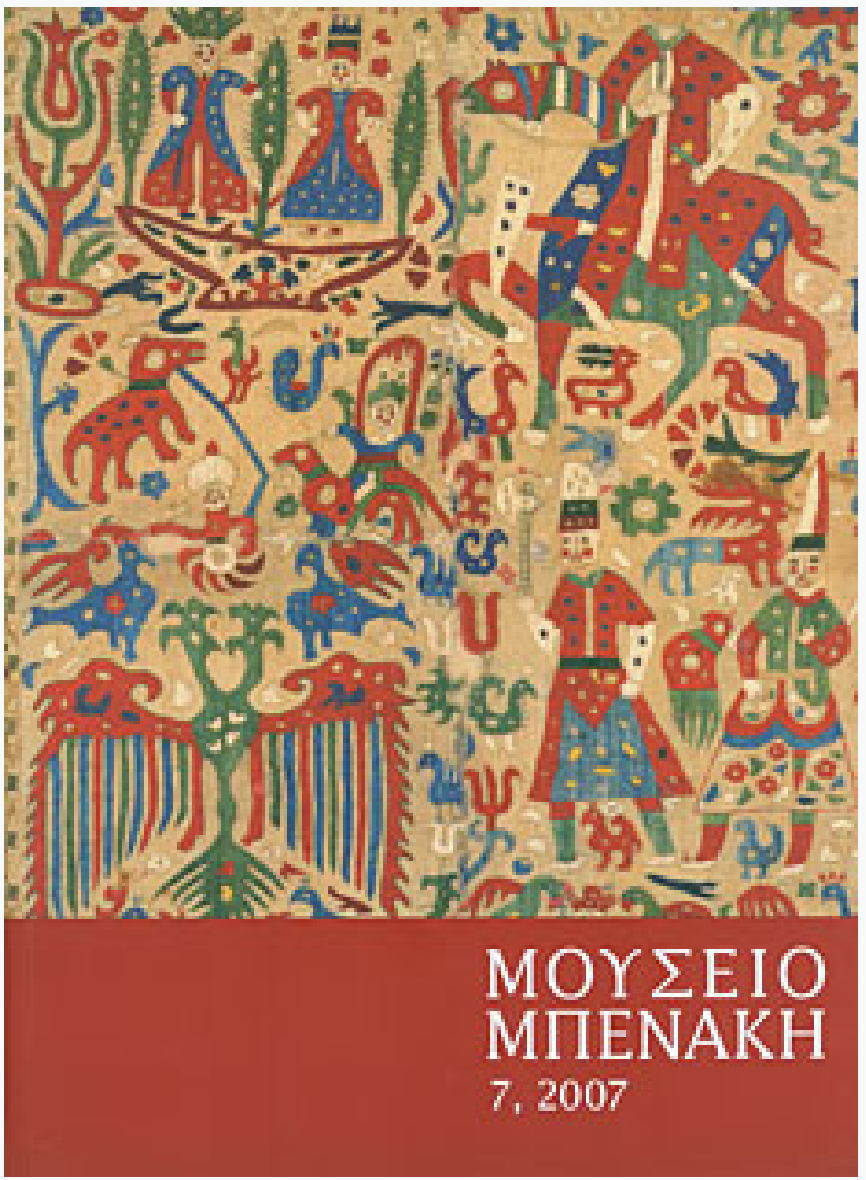

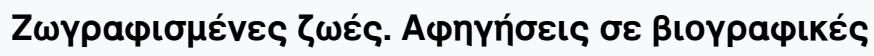

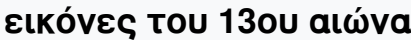

Titos Papamastorakis

doi: $10.12681 /$ benaki.45

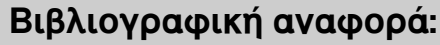

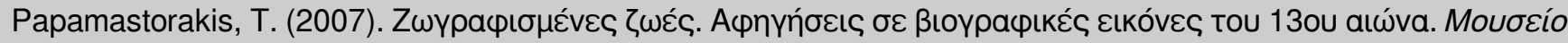
Мпєvákn, 7, 33-65. https://doi.org/10.12681/benaki.45 


\section{Pictorial Lives. Narrative in thirteenth-century vita icons}

TO DATE THREE SUGGESTIONS have been made with regard to the interpretation of 'vita icons', that is icons in which the central figure of a saint is surrounded by scenes from his/her life cycle: (a) the episodes depicted may reflect, but do not consistently follow, known texts; ${ }^{1}$ (b) the scenes are not arranged in chronological order; ${ }^{2}$ and (c) neither their creation nor their location is related to the tomb spaces or the relics of the saints which they depict. ${ }^{3}$

I believe that surrounding the central figure of a saint with episodes from their life is intended to shed light on their identity through the events which led to their sanctification. Consequently the choice of scenes must illustrate the faith of the person depicted and what it achieved: acts, miracles, martyrdom. I also think that vita icons are the visual expression of narrative works, in this case the Lives of Saints, and that therefore following the storyline of these narratives, i.e. depicting successive episodes, marking the key points in the narrative development in each Life, is of fundamental importance.

The 'plot', that is the structuring of the episodes in a story, is a basic element in any narrative. ${ }^{4}$ This plot or storyline is directly connected with time, the dimension within which for the most part the narrative develops. ${ }^{5}$ Similarly in the vita icons, the arrangement of the scenes must express the storyline and correspond to the chronological sequence of events, facilitating an understanding of the relationship between cause and effect given that, by definition, cause precedes effect. It is crucial to show the time sequence clearly; otherwise the scenes will seem like a series of random, unconnected events.

Thus, in terms of visual narratives, I have attempted to look at nine of the fifteen earliest vita icons ${ }^{6}$ produced in the thirteenth century in either the Monastery of St Catherine's, Sinai, or in the Latin Kingdoms of Jerusalem and Cyprus; in other words all coming from the Eastern Mediterranean. I have chosen icons which either preserve the saint's life cycle intact, or, in cases where some scenes have been damaged, preserve enough details to permit identification. The vita icons concerned are: St Catherine, St George, The Prophet Moses and St Panteleimon from the Sinai Monastery; St Prokopios from the Patriarchate in Jerusalem; The Apostle Philip and St John Lampadistis from the churches dedicated to these saints in Cyprus and St Marina from the church of Ayia Marina in Kyperounda in Cyprus, which is now kept in the Museum of the Holy Cross in Kyperounda.

In what follows I shall present the life cycles depicted on these icons, outline the ways in which they can be read and the hagiographical texts on which they are based, showing how the order of the scenes assists the narrative.

1. The vita icon of Saint Catherine in the Sinai monastery has twelve scenes from the life of the saint arranged around the central figure of St Catherine (fig. 1). ${ }^{7}$ The inscriptions which accompany the scenes are misspelt. ${ }^{8} \mathrm{It}$ has been suggested that in this icon scenes do not always follow the exact order of the narrative.?

The first episode in the cycle is inscribed 'the saint at prayer' and depicts Catherine kneeling with her hands in prayer position in the presence of an angel (fig. 2). The scene has been interpreted as the angel visiting Catherine in prison..$^{10}$ This episode follows the imprisonment of the 


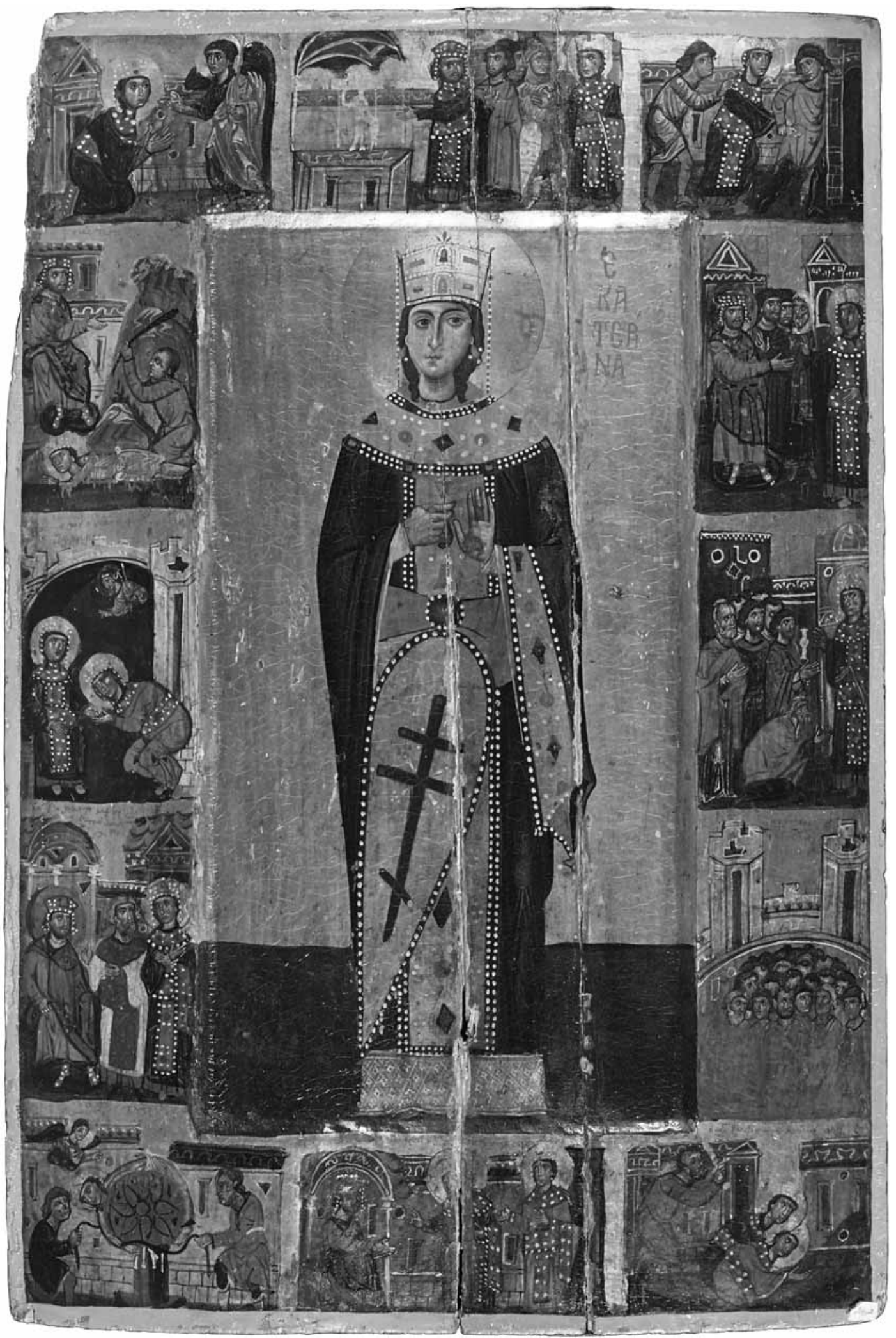

Fig. 1. Vita icon of St Catherine. Sinai, St Catherine's Monastery (photo: Sp. Panayiotopoulos). License from St Catherine's Monastery only for b/w reproductions 


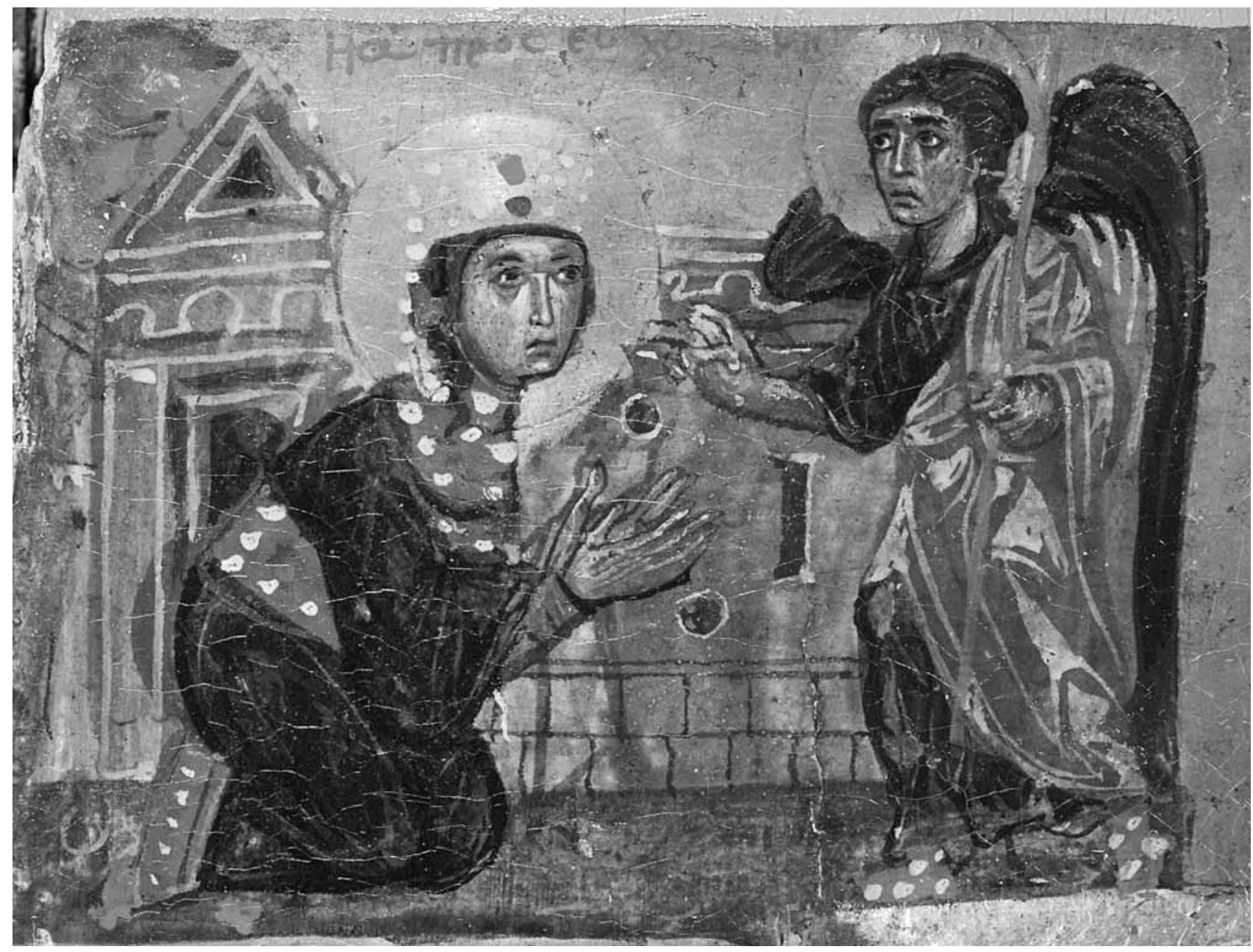

Fig. 2. St Catherine praying. The first scene in the cycle on the vita icon of St Catherine. Sinai, St Catherine's Monastery (photo: Sp. Panayiotopoulos).

saint and it should be the fourth in the cycle. However, the scene does not depict the characteristic prison building, i.e. two towers linked by an arch with crenellations at the top, as in the eighth scene in which the Empress is depicted visiting the saint in prison (fig. 3). On the contrary, the buildings in the background of the first scene suggest a private space and lead us to conclude that the saint is praying in her own home. In my opinion, in depicting the saint's prayer, the painter is representing the phrase: "every day she [Catherine] would address prayers only to God in her

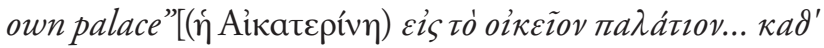

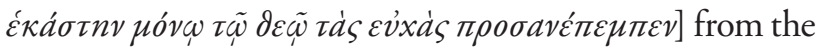
Life of St Catherine in Ms. Par. Gr. 1180, ed. Viteau $\$ 4$ p. $45{ }^{11}$ The inscription 'the saint at prayer' also supports this idea. The depiction of the angel in this first scene comes from a conflation of two separate episodes from the Life: the saint's prayer at home and the appearance of the angel to the imprisoned saint, in order to strengthen her faith and increase her wisdom. The content of the first scene underlines the fact that Catherine was a Christian, endowed with wisdom and divine grace, qualities which would lead to her efforts depicted in the next scene, in which the Christian Catherine takes public action, intervening in an idolatrous sacrifice offered by Maxentios in the temple.

If the misinterpreted first scene is given its proper meaning, it is evident that the twelve scenes of the St Catherine cycle correspond to the Life entitled "Martyrion of the

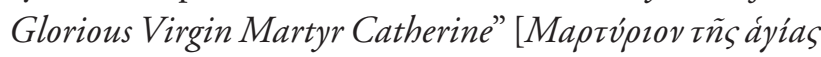

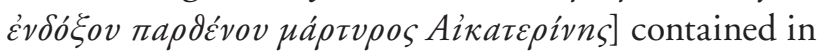
the tenth-century codex Par. Gr. 1180, ed. Viteau ${ }^{12}$ [BHG 


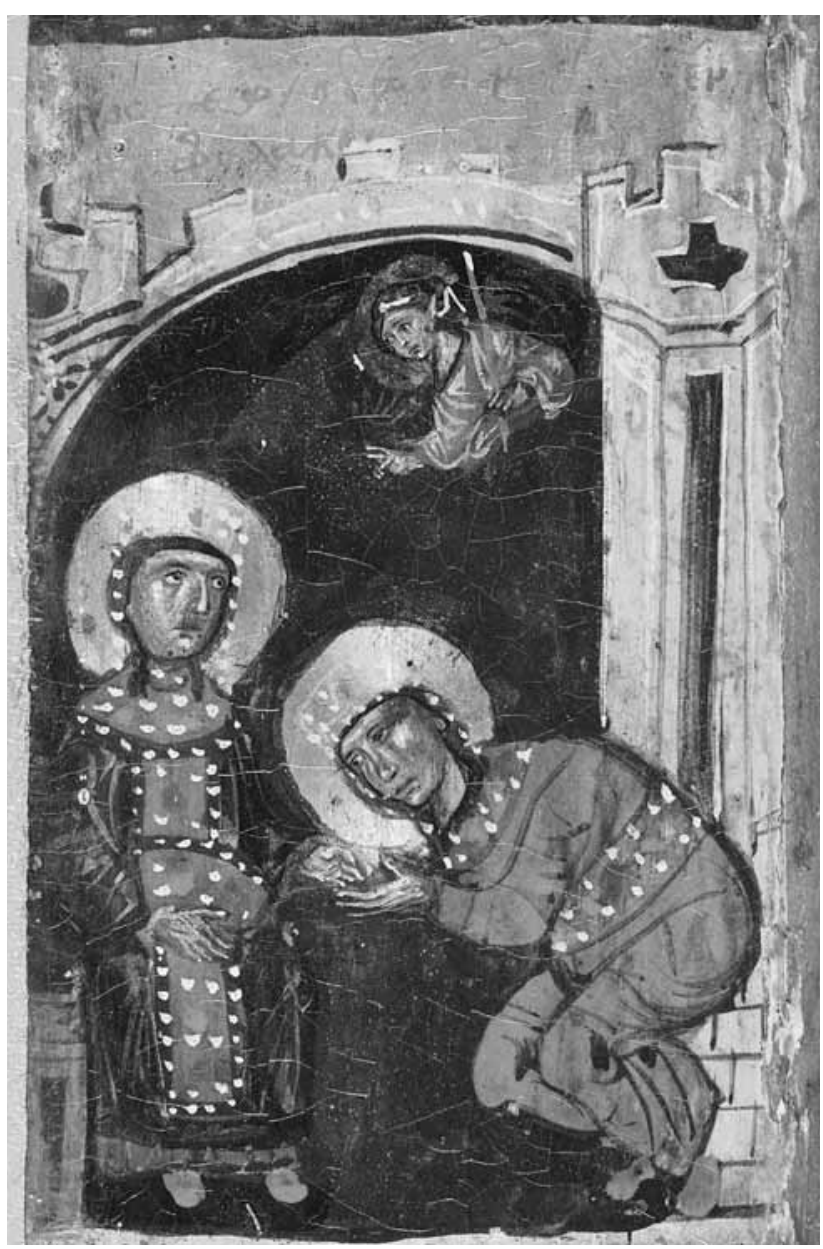

Fig. 3. The Empress falls at Catherine's feet in her prison cell. The eighth scene in the cycle on the vita icon of St Catherine. Sinai, St Catherine's Monastery (photo: Sp. Panayiotopoulos).

31]. A comparison of the text with the life-cycle in the icon of St Catherine shows that the artist followed the narrative of the text faithfully, with no inconsistencies in the sequence of events. The pictorial cycle is arranged as follows: top row from left to right, right-hand side top to bottom, left-hand side top to bottom and bottom row, left to right. The twelve scenes which make up the life-cycle of St Catherine on the Sinai icon correspond to the following extracts from the Life mentioned above:

Top row [1-r]:

1 st scene. Catherine praying at home (Viteau $\$ 4$ p. 45) (fig. 2).

2nd scene. Catherine interrupts Maxentios' sacrifice in the temple (Viteau $\$ 6$ p. 45). 3rd scene. Catherine is arrested and taken to the palace (Viteau $\$ 7-8$ p. 47).

Right-hand side [top to bottom]:

4th scene. Catherine debates with the rhetors (Viteau $\$ 11$ p. 51).

5th scene. The rhetors fall at Catherine's feet (Viteau $₫$ 13 p. 55).

6th scene. The rhetors in the furnace (Viteau $\$ 13$ p. 55).

Left-hand side [top to bottom]:

7 th scene. Catherine, stripped of her imperial dress, is tortured by scourging (Viteau $₫ 14$ p. 57).

8th scene. The Empress falls at Catherine's feet in her prison cell (Viteau $\$ 15$ p. 57) (fig. 3).

9th scene. The eparch Chursasadem advises Maxentios, in the presence of Catherine, to construct the wheel on which she is to be martyred (Viteau $\$ 19$ p. 61).

Bottom row [1-r]:

10th scene. Catherine on the wheel (Viteau $\$ 20$ p. 61).

11th scene. Catherine and the Empress debate with Maxentios (Viteau $\$ 21$ p. 61).

12th scene. The beheading of the Empress (Viteau $\$ 21$ p. 63) and of St Catherine (Viteau $₫ 25$ p. 65). In other words the last two episodes which bring the Life to a close, are compressed into this one scene.

2. The vita icon of Moses from Sinai was originally kept in the chapel on the summit dedicated to the eponymous prophet (fig. 4). ${ }^{13}$ It was commissioned by the archbishop and abbot of the Sinai monastery, Neilos, who is depicted in the central space of the icon in an attitude of prayer at the prophet's feet (fig. 5). ${ }^{14}$ Moses' life-cycle has twenty episodes, beginning at the top of the left-hand border and finishing at the far right-hand side of the bottom row. The scenes in the vertical register are arranged in facing pairs around the central axis and read from left to right and from top to bottom.

The main stumbling block in the narration of the Moses cycle is the eleventh scene, which depicts one of the miracles Moses works with water (fig. 6). On the basis of its inscription - "when the rock was split, water flowed"-this scene has been identified with the episode on Mount Horeb when Moses struck the rock and water gushed out (Exodus 17:16). ${ }^{15}$ But the circular spring in the foreground of the composition with its wide mouth, into which Moses plunges his rod, and which is clearly differentiated from the mountainous landscape in the background, is more likely to refer to 


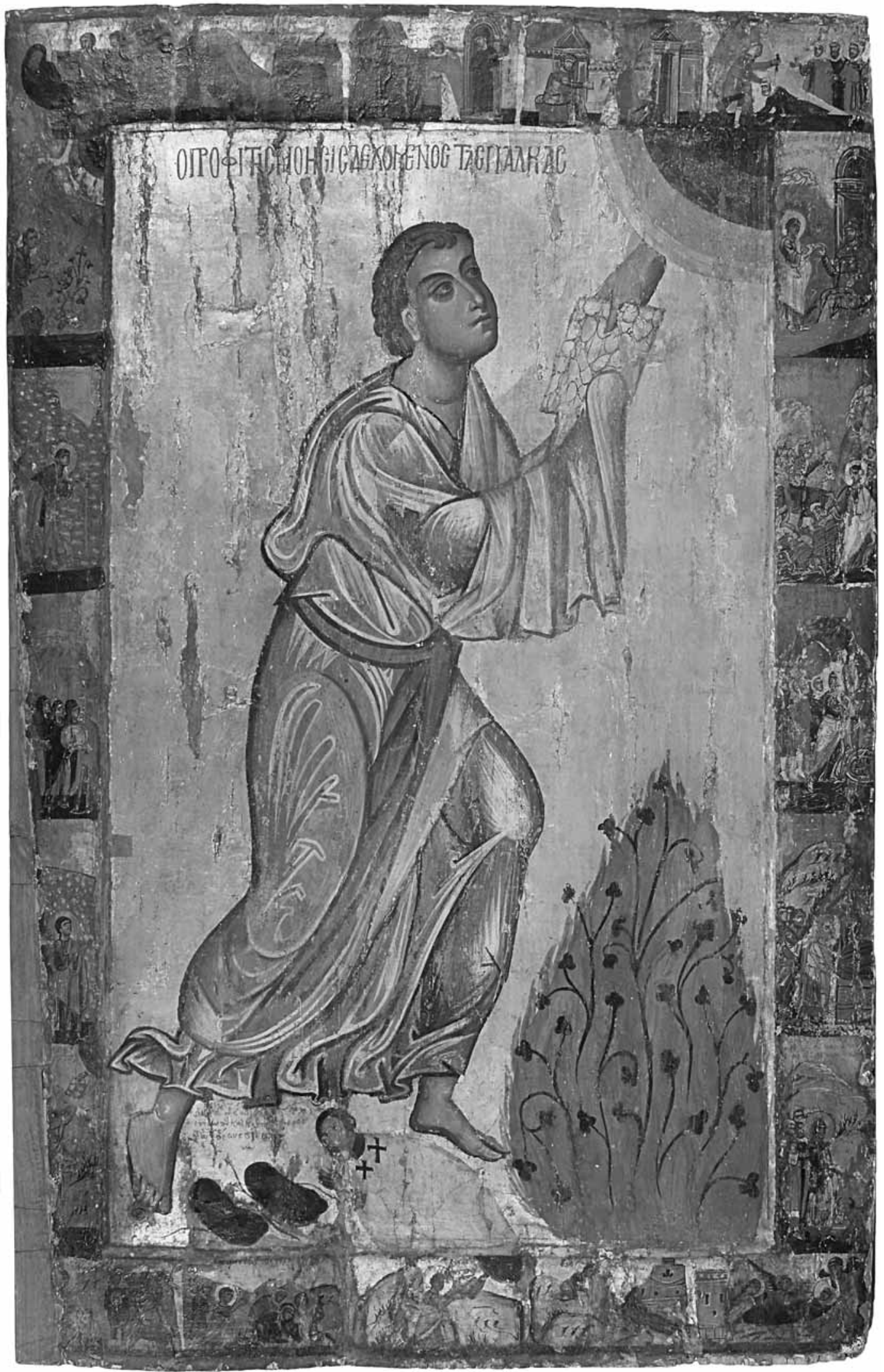

Fig. 4. The vita icon of the Prophet Moses. Sinai, St Catherine's Monastery (photo: Sp. Panayiotopoulos). 

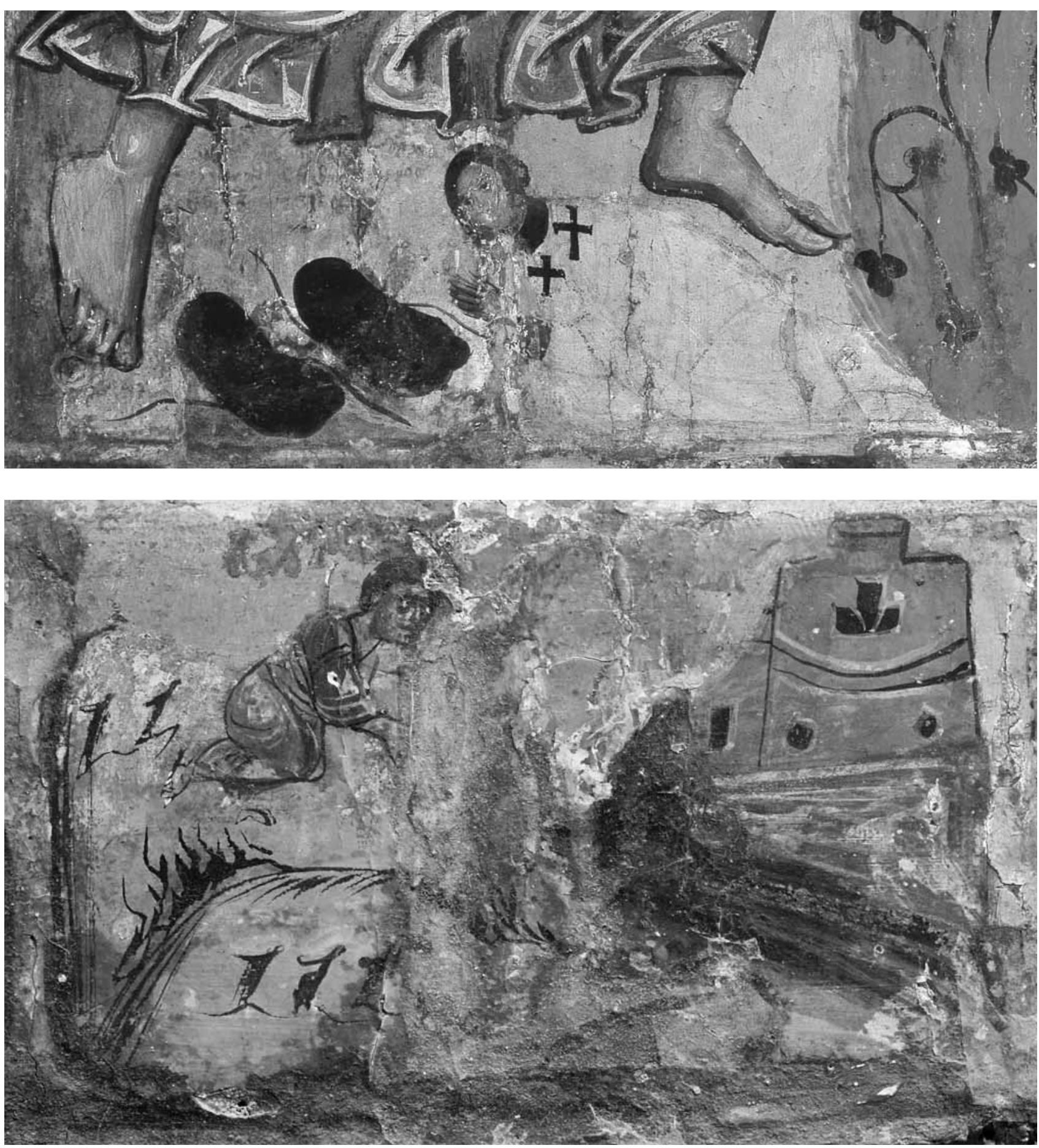

Fig. 5. Neilos, Archbishop and Abbot of the Sinai Monastery, donor of the vita icon of the Prophet Moses. Sinai, St Catherine's Monastery (photo: Sp. Panayiotopoulos).

Fig. 7. The Prophet Moses praying to see the Promised Land. The nineteenth scene in the cycle on the vita icon of the Prophet Moses. Sinai, St Catherine's Monastery (photo: Sp. Panayiotopoulos). 
the turning of the 'bitter' water at the oasis of Marah into drinkable water (Exodus 15: 23-25). So, if this scene is dissociated from its erroneous inscription, then the sequence of the narration is faithfully followed in all twenty scenes on this vita icon. The inscription attached to the eleventh scene is associated with the miracle on Mount Horeb and must be due to the artist's efforts to adapt this scene to the holy place in which the icon was kept. ${ }^{16}$ There is a similar example in the nineteenth scene in which Moses prays to see the Promised Land (fig. 7). On the basis of the inscription - "Moses prays to see Jerusalem" - the city depicted on the right-hand side has been recognized as Jerusalem, though its name is never mentioned in Deuteronomy. However, the city which, according to Deut. 34, 1, should be depicted is Jericho. But the artist was inspired to show the special relationship between the monastery at Sinai and Jerusalem. ${ }^{17}$

The life-cycle of the Prophet Moses depicted on the icon from Sinai corresponds to the following passages from the bible:

Top row [1-r]:

1st scene. Birth of Moses (Exodus 2: 1-2).

2nd scene. Moses' Exposure in the Nile and discovery by Pharaoh's daughter (Exodus 2: 3-5).

3rd scene. Pharaoh sits holding the child Moses on his knee (Midrash Rabbah Exodus 1: 26).

4th scene. The trial of Moses with the burning coal (Midrash Rabbah Exodus 1: 26).

5th scene. Moses slaying the Egyptian (Exodus 2: 11-12).

Vertical sides:

Left, 6th scene. Moses and the burning bush (Exodus 3: 1-6).

Right, 7th scene. Moses before Pharaoh (Exodus 5: 1-5). Left, 8th scene. The plague of hail (Exodus 9: 23-25).

Right, 9th scene. The crossing of the Red Sea (Exodus 14: 19-29) (fig. 8).

Left, 10th scene. Miriam and the Israelite women celebrating after the crossing of the Red Sea (Exodus 15: 20-21).

Right, 11th scene. Moses turns the bitter waters of Marah into drinking water (Exodus 15: 23-25) (fig. 6).

Left, 12th scene. The miracle of the manna and the quails (Exodus 16: 13-31).

Right, 13th scene. Aaron officiating (Exodus 16: 32-34).

Left, 14th scene. Moses receiving the Tablets of the Law (Exodus 31: 18).

Right, 15th scene. Aaron and the golden calf (Exodus 32: 1-4).

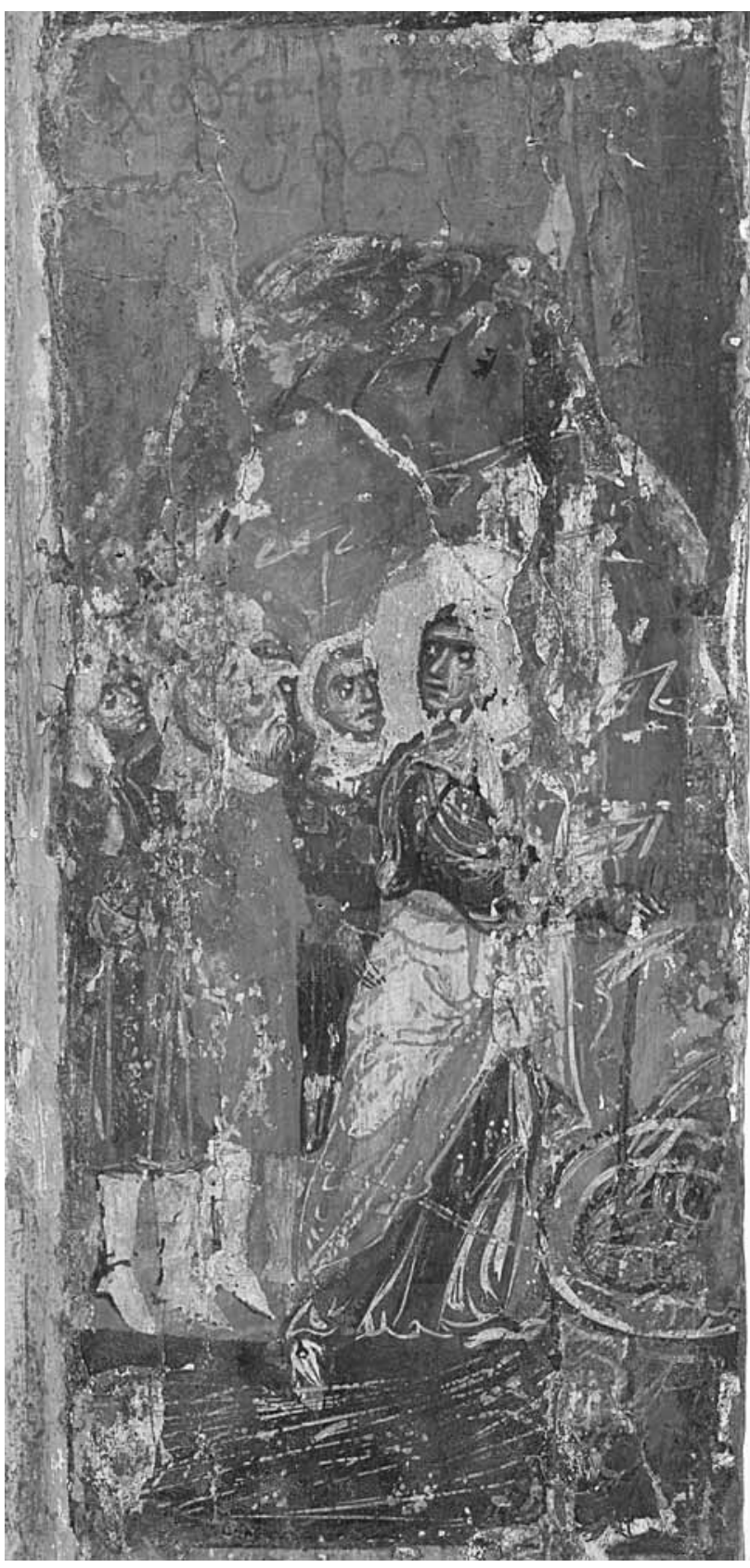

Fig. 6. The Prophet Moses turning the bitter water of Marah into drinking water. The eleventh scene in the cycle on the vita icon of the Prophet Moses. Sinai, St Catherine's Monastery (photo: Sp. Panayiotopoulos). 


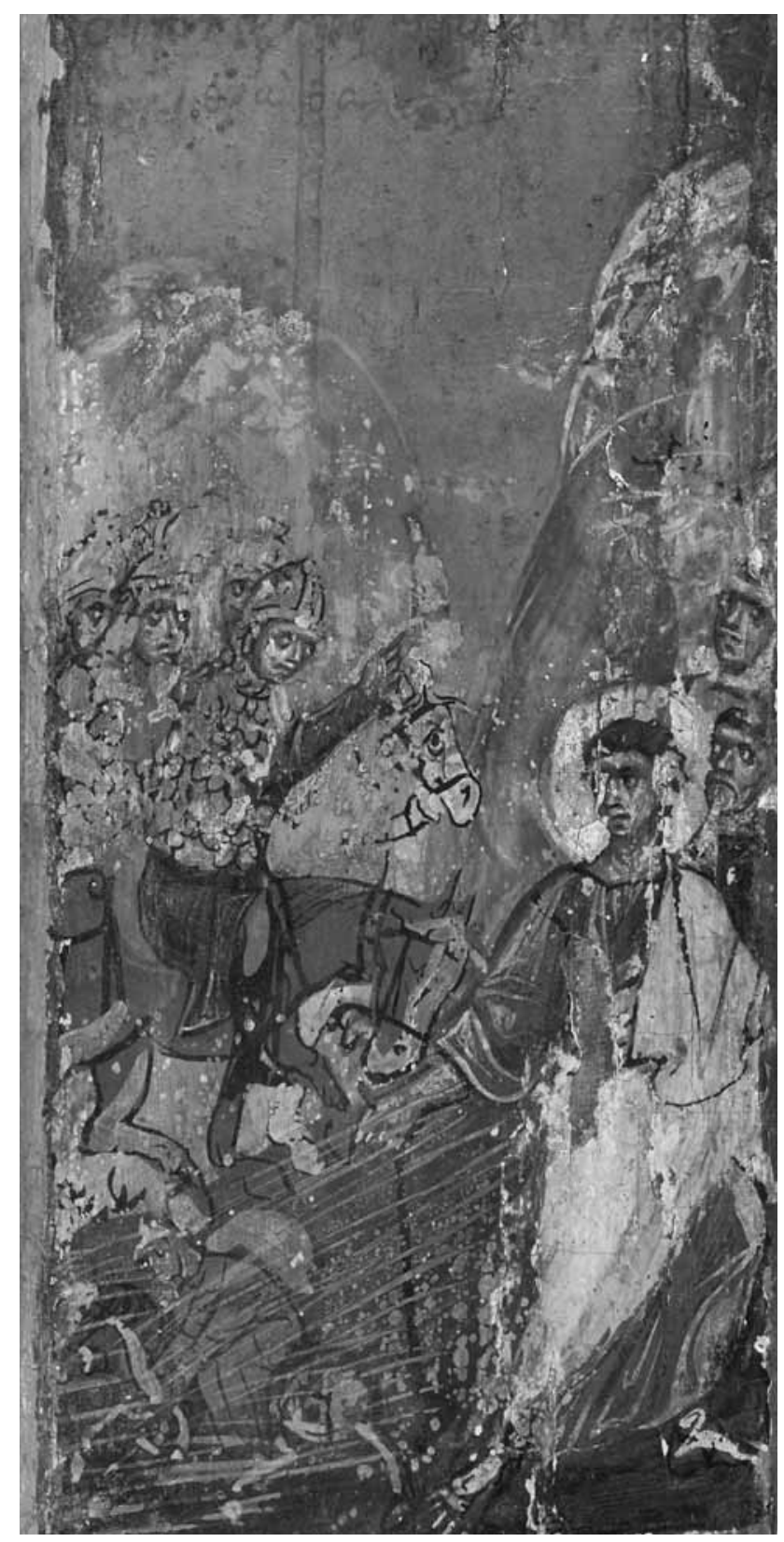

Fig. 8. The crossing of the Red Sea. The ninth scene in the cycle on the vita icon of the Prophet Moses. Sinai, St Catherine's Monastery (photo: Sp. Panayiotopoulos).
Bottom row [1-r]:

16th scene. Moses breaking the Tablets of the Law (Exodus 32: 19).

17 th scene. Moses ordering the sons of Levi to slay the idolaters (Exodus 32: 27-28).

18th scene. Moses receiving the new Tablets of the Law (Exodus 34: 4-5).

19th scene. Moses praying to see the Promised Land (Deut. 34, 1) (fig. 7).

20th scene. The burial of Moses by angels (Deut. 34, 5-6).

3. The vita icon of St Panteleimon from St Catherine's, Sinai was originally kept in the church dedicated to the saint outside the walls of the monastery (fig. 9). ${ }^{18}$ The cycle is made up of sixteen episodes, which are accompanied by misspelt inscriptions. ${ }^{19}$ The narration begins top left with the meeting between Pantoleon (Panteleimon) and the Christian Hermolaos (fig. 10) and ends with the burial of the saint in the lower right-hand corner. The scenes on the vertical sides of the icon are arranged in facing pairs around the central axis and read from left to right and top to bottom.

The sixteen scenes in the cycle are thought to have created a new version of the saint's martyrion, based mainly on the Life which Symeon Metaphrastes compiled, but also on other lives, because some of the episodes do not correspond to the Metaphrastian text. ${ }^{20}$ Moreover, based on the erroneous inscription in the second scene (fig. 11), "St Panteleimon learning the art of medicine", scholars have interpreted the fact that the artist chose to begin the cycle with Pantoleon meeting the Christian Hermolaos and his initiation into Christianity by him as a deviation from the Life. ${ }^{21}$ It has also been suggested that the scenes are depicted out of order. ${ }^{22}$

The fifth scene (fig. 12), mistakenly inscribed "the saint killing the snake", depicts Pantoleon showing Hermolaos the snake which he has already killed, when the latter asks him to do it as a token of his faith in preparation for baptism. This episode is absent both from the Encomium written by Niketas David the Paphlagonian and from the Life compiled in honour of St Panteleimon by Symeon Metaphrastes. Linking this with other iconographical details indicates that the painter was following either the Passio A, that is the Life entitled "Martyrion of the holy

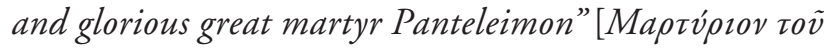




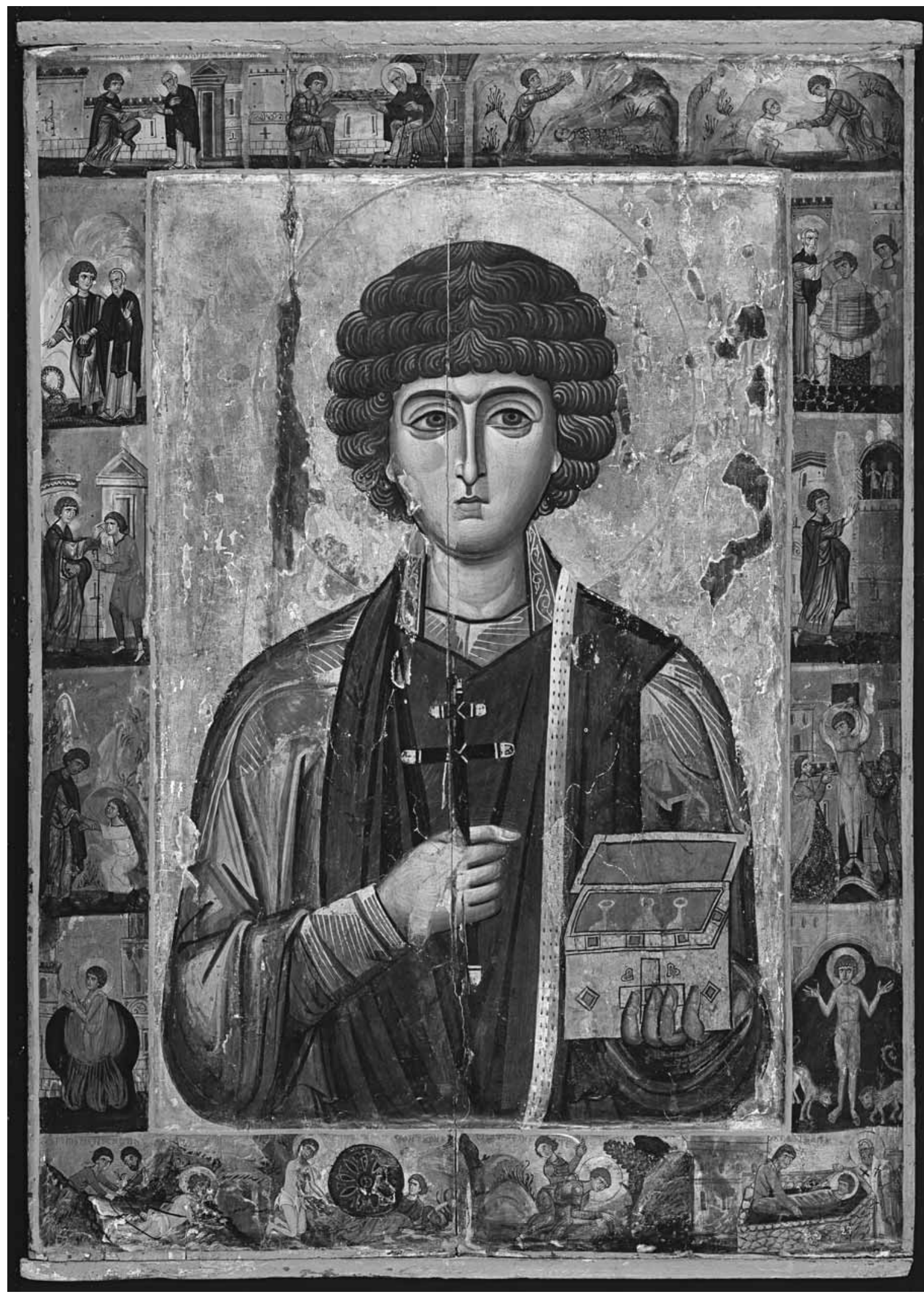

Fig. 9. The vita icon of St Panteleimon. Sinai, St Catherine's Monastery (photo: Sp. Panayiotopoulos). 

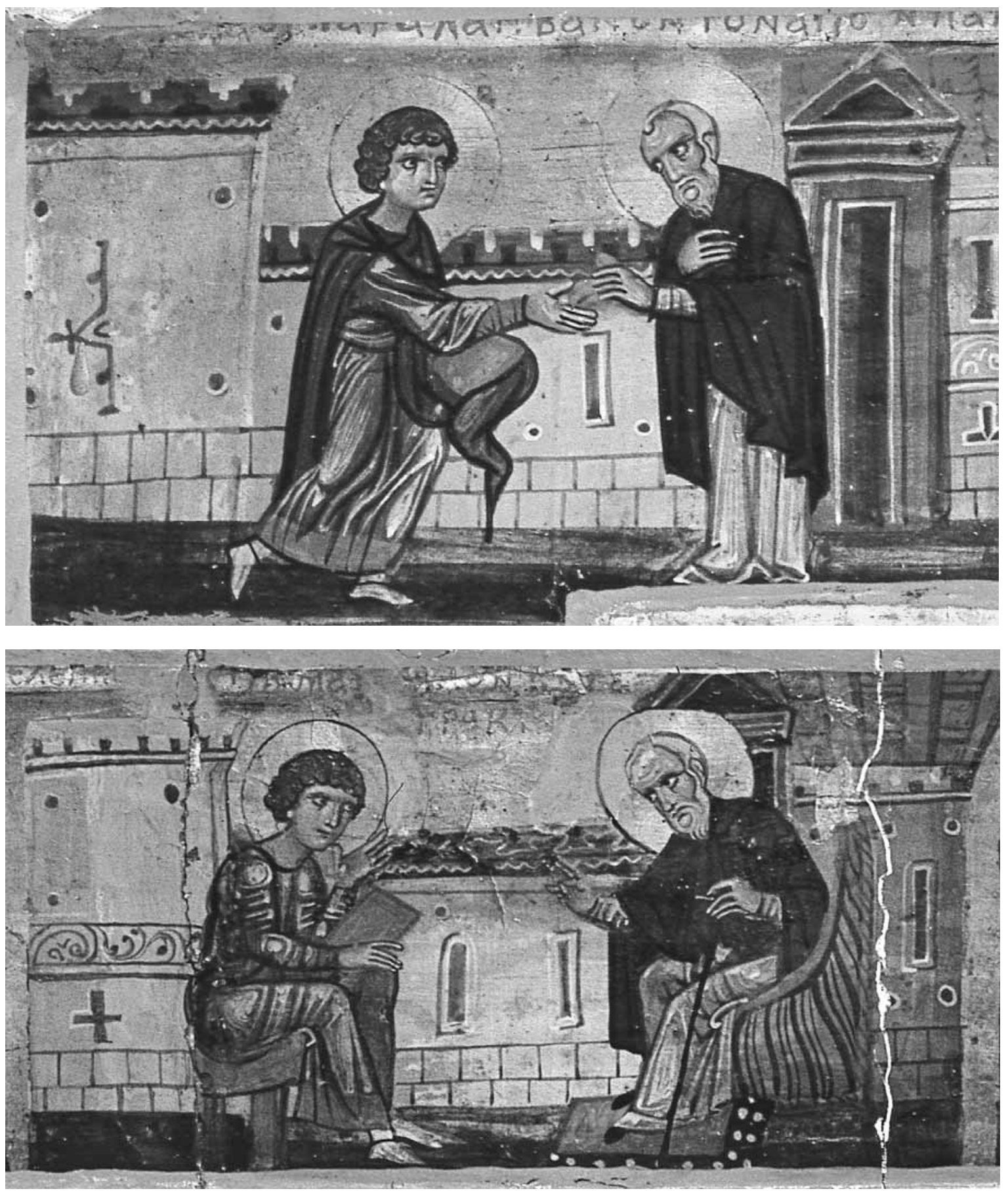

Fig. 10. Pantoleon meets Hermolaos. The first scene in the cycle on the vita icon of St Panteleimon. Sinai, St Catherine's Monastery (photo: Sp. Panayiotopoulos).

Fig. 11. Hermolaos inducts Pantoleon into the Christian faith. The second scene in the cycle on the vita icon of St Panteleimon. Sinai, St Catherine's Monastery (photo: Sp. Panayiotopoulos). 


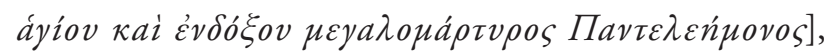
which has come down to us in the eleventh-century Moscow codex 161 (Vladimir 379) ff. 135-45, ed. Latysev ${ }^{23}$ [BHG 1412z], or John Geometres' Encomium of the Great Martyr Saint Panteleimon in iambics ['Eykẃurov

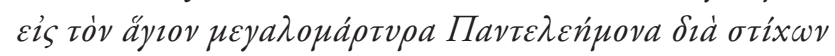
ia $\beta \imath \kappa \tilde{\omega} v]$, ed. Sternbach ${ }^{24}$ [BHG 1415], which depends to a large extent on the Passio A.

The episodes in the cycle follow the sequence established in the above mentioned texts, except for the scene at the bottom of the right-hand column, which should be in the place occupied by the first scene in the bottom row. The artist has intentionally switched the places of the two scenes purely for reasons of space. The scene with Pantoleon in the stadium needs a tall space, whereas the scene where Pantoleon is being thrown into the sea requires breadth. The pictorial organization of these two scenes does not allow them to be placed in the correct positions: the first one could not be fitted into the horizontal space, while the second would not fit into a vertical space.

The episode of the idols' destruction depicted in the eighth scene shows Pantoleon instead of his father Eustorgios. According to the vita it was Eustorgios who destroyed the idols after having witnessed his son healing the blind man, the episode depicted in the seventh scene. The artist most probably copied an older painting but did not interpret it correctly and replaced Eustorgios' figure with Pantoleon's.

The episodes which make up the cycle of St Panteleimon on the Sinai icon correspond to the following passages from the Vladimir cod. 379 (Passio A) and the metrical encomium by John Geometres:

Top row [1-r]:

1st scene. Pantoleon meets Hermolaos (Passio A $\$ 2$ p. 40.25-30 = John Geometres 11. 79-83) (fig. 10).

2nd scene. Hermolaos teaches Pantoleon about the Christian faith (Passio A $\$ 2$ p. 41.2-25 = John Geometres 11. 166-73) (fig. 11).

3rd scene. Pantoleon prays for the child to be revived (Passio A \$ 4 p. 42.1-9 = John Geometres 11. 174-96).

4th scene. Pantoleon resurrects the child (Passio A $₫ 4$ p. 42.9-10 = John Geometres 11. 197-207).

Vertical sides:

Left, 5th scene. Pantoleon shows Hermolaos the dead snake (Passio A $\$ 4$ p. 42.18-22 = John Geometres 11. 22029) (fig. 12).

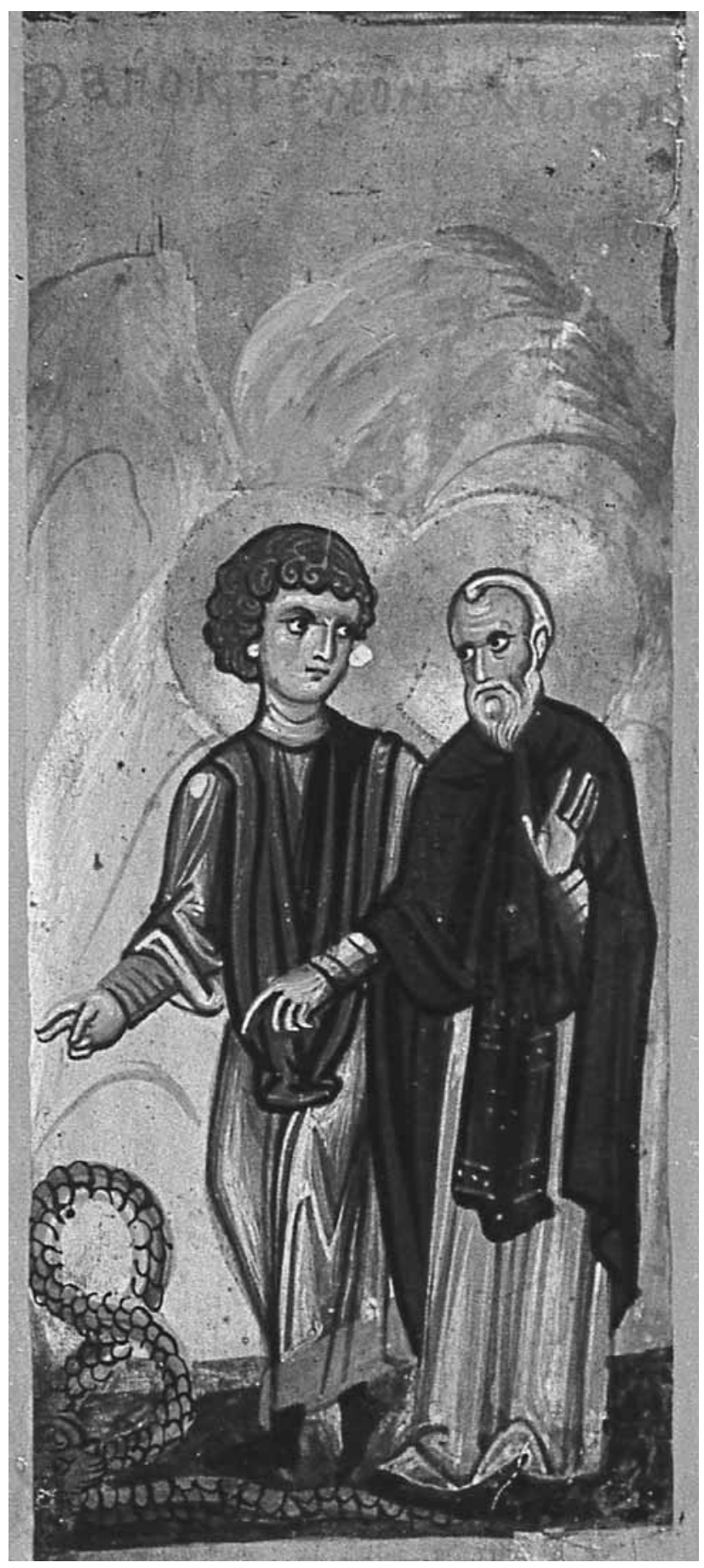

Fig. 12. Pantoleon shows Hermolaos the dead snake. The fifth scene in the cycle on the vita icon of St Panteleimon. Sinai, St Catherine's Monastery (photo: Sp. Panayiotopoulos). 


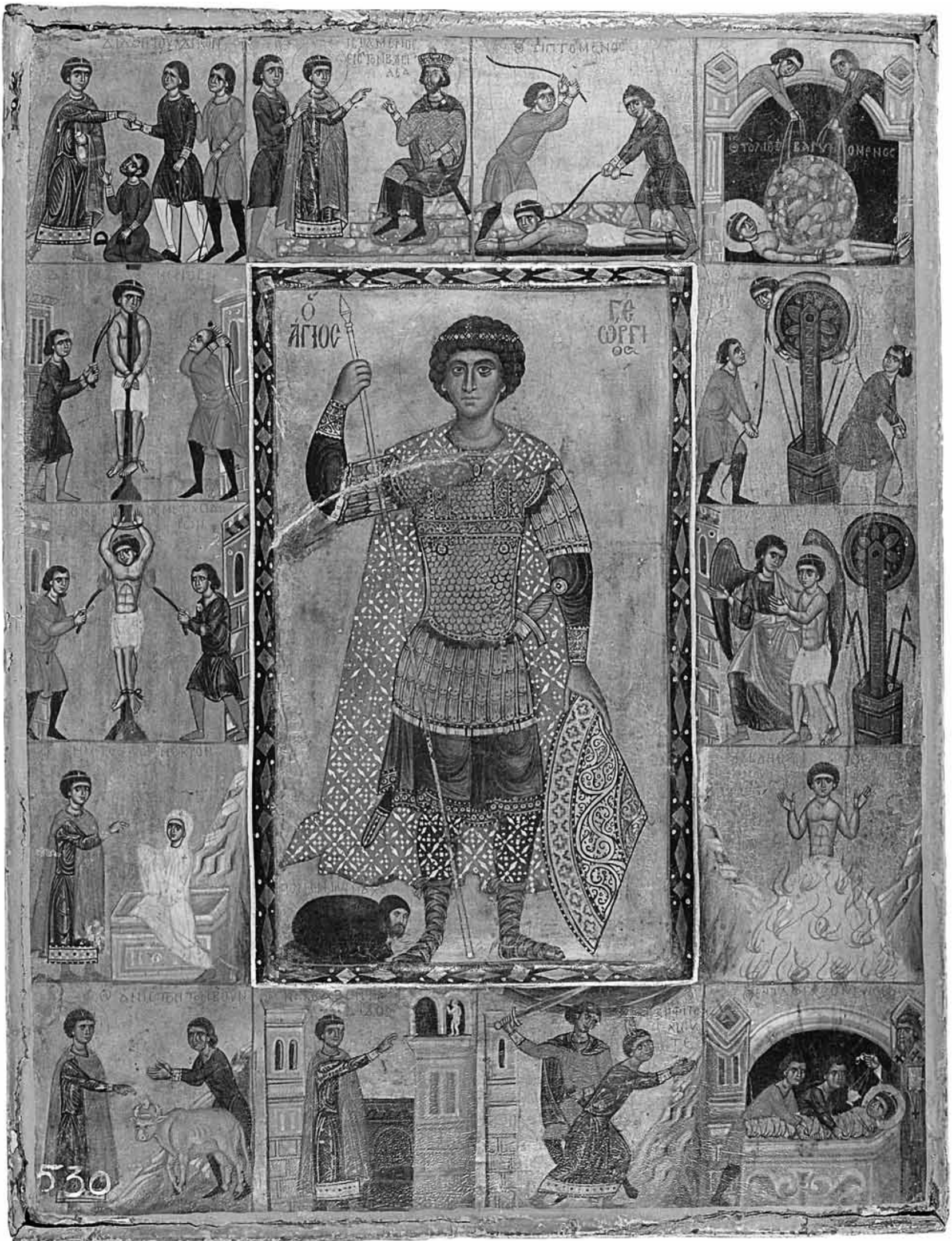

Fig. 13. The vita icon of St George. Sinai, St Catherine's Monastery (photo: Sp. Panayiotopoulos). 
Right, 6th scene. Baptism of Pantoleon (Passio A $\$ 5$ p. 42.23-4 = John Geometres 11. 246-50).

Left, 7th scene. Pantoleon heals the blind man (Passio A $\$ 7$ p. 44.2-8 = John Geometres 11. 410-20).

Right, 8th scene. Pantoleon destroys the idols (Passio A $\$ 6$ p. 44.18-19 = John Geometres 11. 421-25).

Left, 9th scene. Pantoleon heals the paralytic (Passio A $\$ 14$ p. 47.2-4 = John Geometres 11. 668-70).

Right, 10th scene. Pantoleon burnt with torches (Passio A $\$ 16$ p. 47.27-8 = John Geometres 11. 735-43).

Left, 11th scene. Pantoleon in the boiling cauldron (Passio A $₫ 17$ p. 48.11-26 = John Geometres 11. 785-809).

Right, 12th scene. Pantoleon in the arena with the wild animals (Passio A $₫ 20$ p. 49.25-30 = John Geometres 11 . 845-53).

Bottom row [1-r]:

13th scene. Pantoleon is thrown into the sea (Passio A $\$$ 18 p. 48.30-5 = John Geometres 11. 825-27).

14th scene. Pantoleon is saved while the executioners are crushed by the wheel (Passio A $\$ 22$ p. 50.19-22 = John Geometres 11. 883-89).

15th scene. Beheading of Panteleimon (Passio A $\$ 26 \mathrm{p}$. 52.16-33 = John Geometres 11. 1030-33).

16th scene. Burial of Panteleimon (Passio A $\$ 28$ p. 53.9-13 = John Geometres 11. 1034-35).

4. The vita icon of St George from St Catherine's, Sinai has fourteen scenes around the central figure of the saint, each scene accompanied by an inscription (fig. 13). ${ }^{25}$ It was commissioned by the monk Poimen, who is depicted in the central part of the icon in an attitude of prayer at the feet of the full-length figure of St George (fig. 14). The icon, which is now covered in several layers of varnish, was originally dated by the Sotirious to the fifteenth century and, more recently by Doula Mour$\mathrm{iki}$, to the thirteenth century. ${ }^{26}$ This earlier dating is supported by certain iconographic elements which are found in 'crusader' icons from the second half of the thirteenth century. The narrative begins on the left-hand side of the top row with the saint distributing his wealth to the poor and continues first down the right-hand side and then the left, ending at the right-hand end of the bottom row with the saint's burial.

It is possible to identify the text which the life-cycle of St George on the Sinai icon is following on the basis of three episodes: the saint's ordeal by iron nails, depicted

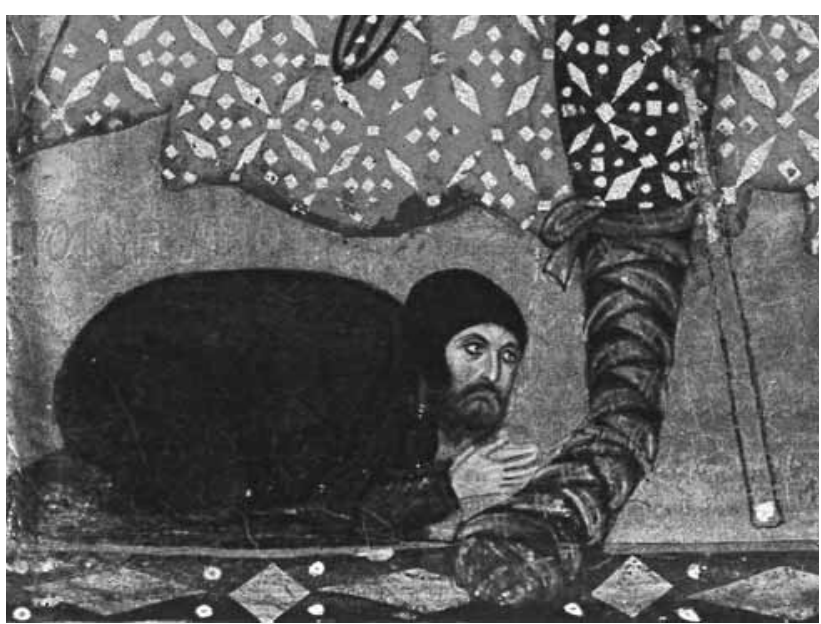

Fig. 14. The monk Poimen, donor of the vita icon of St George. Sinai, St Catherine's Monastery (photo: Sp. Panayiotopoulos).

in the third scene (fig. 15), the trial by burning torches, depicted in the ninth scene (fig. 16) and the burial of the saint in the fourteenth scene (fig. 17) which ends the cycle. These three episodes are not contained in the so-called Normaltext $\mathrm{t}^{27}$ or in the Life written by Niketas David the Paphlagonian, ${ }^{28}$ nor in the Life which Symeon Metaphrastes included in his Menologion..$^{29}$ But they are commemorated in the Life entitled: "Martyrion of the glorious saint and great martyr George" [Ma

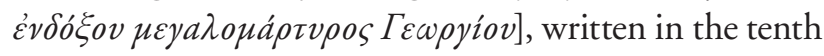
century by Theodore Daphnopates and preserved in two twelfth-century manuscripts, Par. Gr. 1529 ff. 184 ${ }^{\mathrm{r}}-208^{\mathrm{r}}$, ed. Krumbacher ${ }^{30}$ [BHG 673] and Par. Gr. 1178 ff. 171 $1^{\text {v- }}$ 196r, ed. Latysev ${ }^{31}$ [BHG 674].

All the episodes in the cycle are arranged in the same sequence as in Daphnopates' narrative except for the scene of the trial by burning torches which is the ninth scene in the cycle. According to the Daphnopates text, this ordeal follows the two miracles, the Raising of Tobit and the Raising of Glykerios' bull, depicted in tenth and eleventh place respectively, and before the destruction of the idols, which is depicted in twelfth place. The ordeal by burning torches has been put in this place deliberately (that is, before the two miracles which according to the Life preceded it) so as to complete the section with the ordeals and follow it up with the section made up of the three miracles.

The scenes in the life-cycle of St George on the Si- 


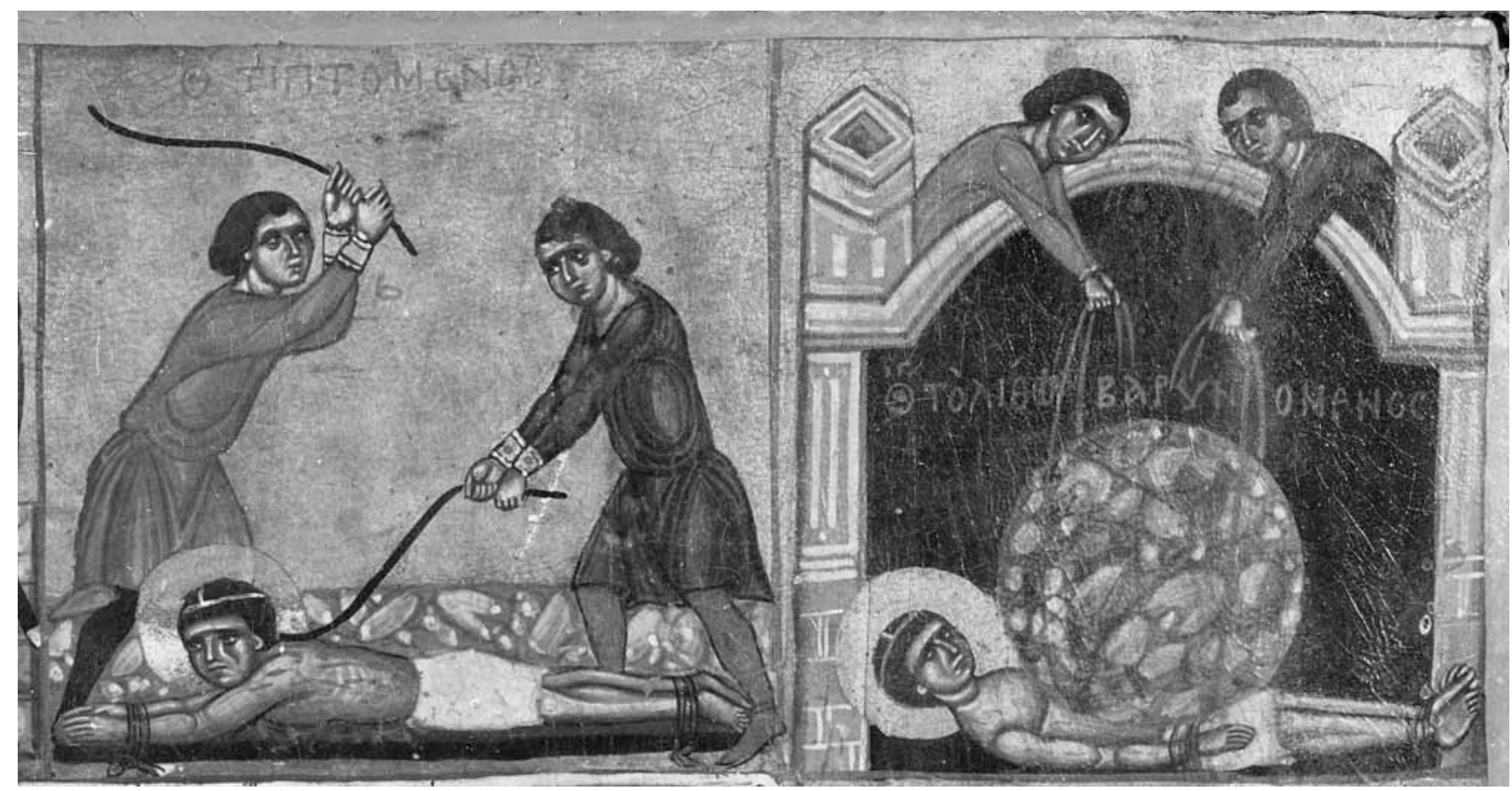

Fig. 15. Left: The ordeal by iron nails. Right: George being stoned in prison. The third and fourth scenes in the cycle on the vita icon of St George. Sinai, St Catherine's Monastery (photo: Sp. Panayiotopoulos).

nai icon correspond to the following passages in Daphnophates's text:

Top row [1-r]:

1st scene. George distributes his wealth to the poor (Krumbacher p. 62.1-3 = Latysev $\$ 8$ p. 6.18-20).

2nd scene. George debating with Diocletian (Krumbacher p. 63.1-36 = Latysev $\$ 8-11$ p. 6-10).

3 rd scene. George scourged with iron nails (Krumbacher p. 64.11-12 = Latysev $\$ 13$ p. 10.26-27) (fig. 15).

4th scene. George being stoned in prison (Krumbacher p. 64.14-22 = Latysev $\$ 13$ p. 10.30-11.2) (fig. 15).

Right-hand side [top to bottom]:

5 th scene. George on the wheel (Krumbacher p. 64.3465.6 = Latysev $\$ 15$ p. 11.26-12.12).

6 th scene. George saved by an angel (Krumbacher p. 65.7-22 = Latysev $\$ 16$ p. 12.27-29).

7th scene. George in the lime pit (Krumbacher p. 66.37$67.10=$ Latysev $\$ 21$ p. 15.19-22).

Left-hand side [top to bottom]:

8th scene. George scourged with whips (Krumbacher p. 69.10-11 = Latysev $\$ 28$ p. 19.28-29) (fig. 16).

9th scene. George burnt with lighted torches (Krum- bacher p. 74.11-12 = Latysev $\$ 42$ p. 29.21-24) (fig. 16).

10th scene. The raising of Tobit (Krumbacher p. 69.1370.5, esp. p. 69.28-70.5 = Latysev $\$ 29$ p. 20.26-21.11).

Bottom row [1-r]:

11th scene. The raising of Glykerios' ox (Krumbacher $\mathrm{p}$. 70.26-71.4 = Latysev $\$ 32$ p. 22.18-23.12).

12th scene. George destroys the idols (Krumbacher p. 75.13-40, especially p. 75.35-40 = Latysev $₫ 47$ p. 32.827).

13th scene. Beheading of George (Krumbacher p. 77.35-6 = Latysev $\$ 54$ p. 36.22-24).

14 th scene. Burial of George (Krumbacher p. 77.37-40 $=$ Latysev $\$ 54$ p. 36.24-30) (fig. 17).

5. The vita icon of St Prokopios kept in the Patriarchate in Jerusalem is traditionally thought to have come from the alleged tomb of the saint in St Prokopios' church in Deir Abu Thor ${ }^{32}$ (fig. 18). The life-cycle around the central figure of the saint consists of seventeen episodes from his life. The narrative begins at the top left-hand side (i.e. the beginning of the top row) with Diocletian bestowing on Neanias (Prokopios) the title of Duke of Alexandria, 


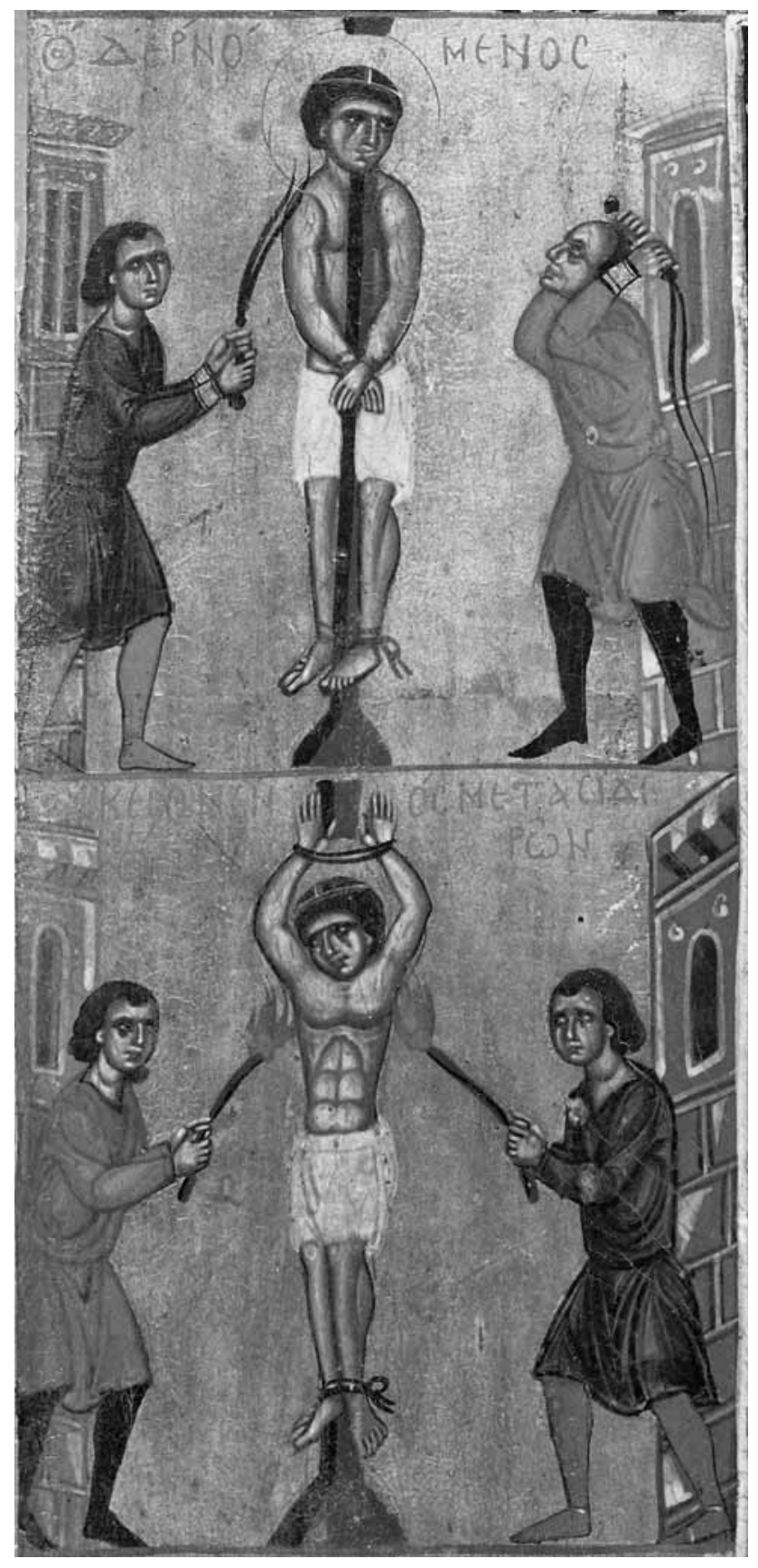

Fig. 16. Up: George scourged with whips. Down: The ordeal by lighted torches. The eighth and ninth scenes in the cycle on the vita icon of St George. Sinai, St Catherine's Monastery (photo: Sp. Panayiotopoulos).

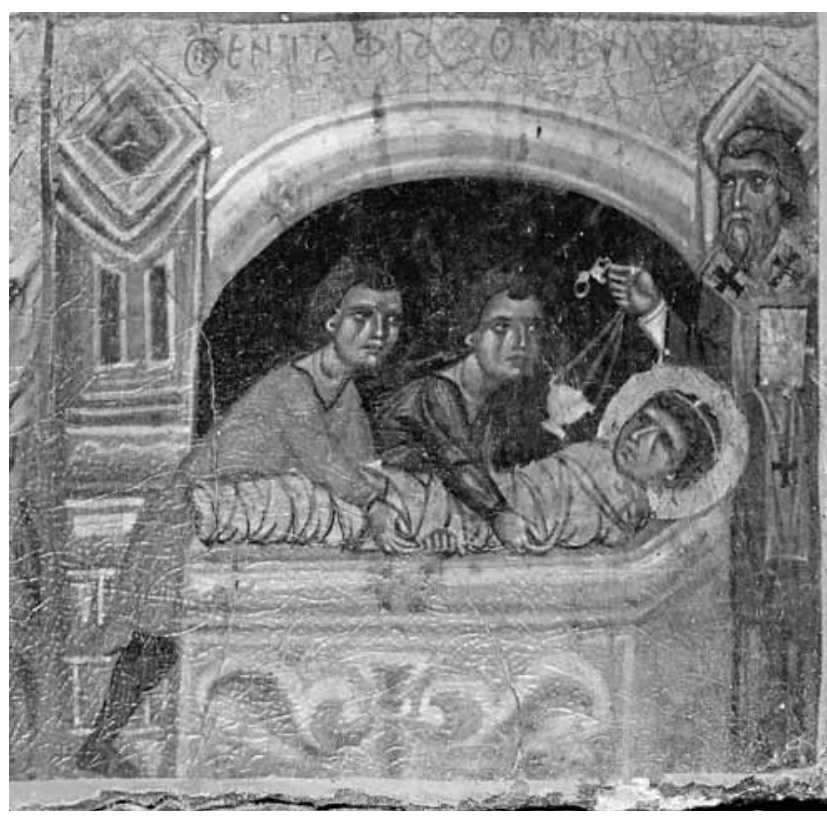

Fig. 17. The burial of St George. The final scene in the cycle on the vita icon of St George. Sinai, St Catherine's Monastery (photo: Sp. Panayiotopoulos).

in which capacity he appears in the next nine scenes, and ends with the burial of the saint in the lower right-hand corner (i.e. at the end of the bottom row). The transition from the first part of the cycle, in which the saint is shown as Neanias, to the second, in which the saint appears as Prokopios comes in the eleventh scene and subsequent scenes develop the theme of his by now supernatural powers. Apart from the burial scene, which is inscribed "The Dormition" [H KHMICHC], none of the scenes have inscriptions. Only the figure of the saint is accompanied by an inscription: "О АГІОС ПРОКОПІОС" [Saint Prokopios]. The depiction of the ciborium of the Saint Sepulchre over the saint's tomb in the scene of his burial suggests that the artist saw this as a way of showing that the martyr's tomb was in Jerusalem; ${ }^{33}$ according to tradition, the vita icon of Prokopios was placed next to his tomb.

All seventeen scenes in the cycle are in chronological order and correspond to the Life of the saint entitled "Martyrion of the holy and glorious martyr Prokopios"

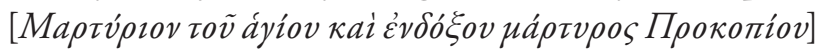
preserved in the tenth-century codex Par. Gr. $1447 \mathrm{ff}$. 269-88, ed. Halkin ${ }^{34}$ [BHG 1577d] and in the Life entitled "Life and Martyrion of St Prokopios and his disciples" 


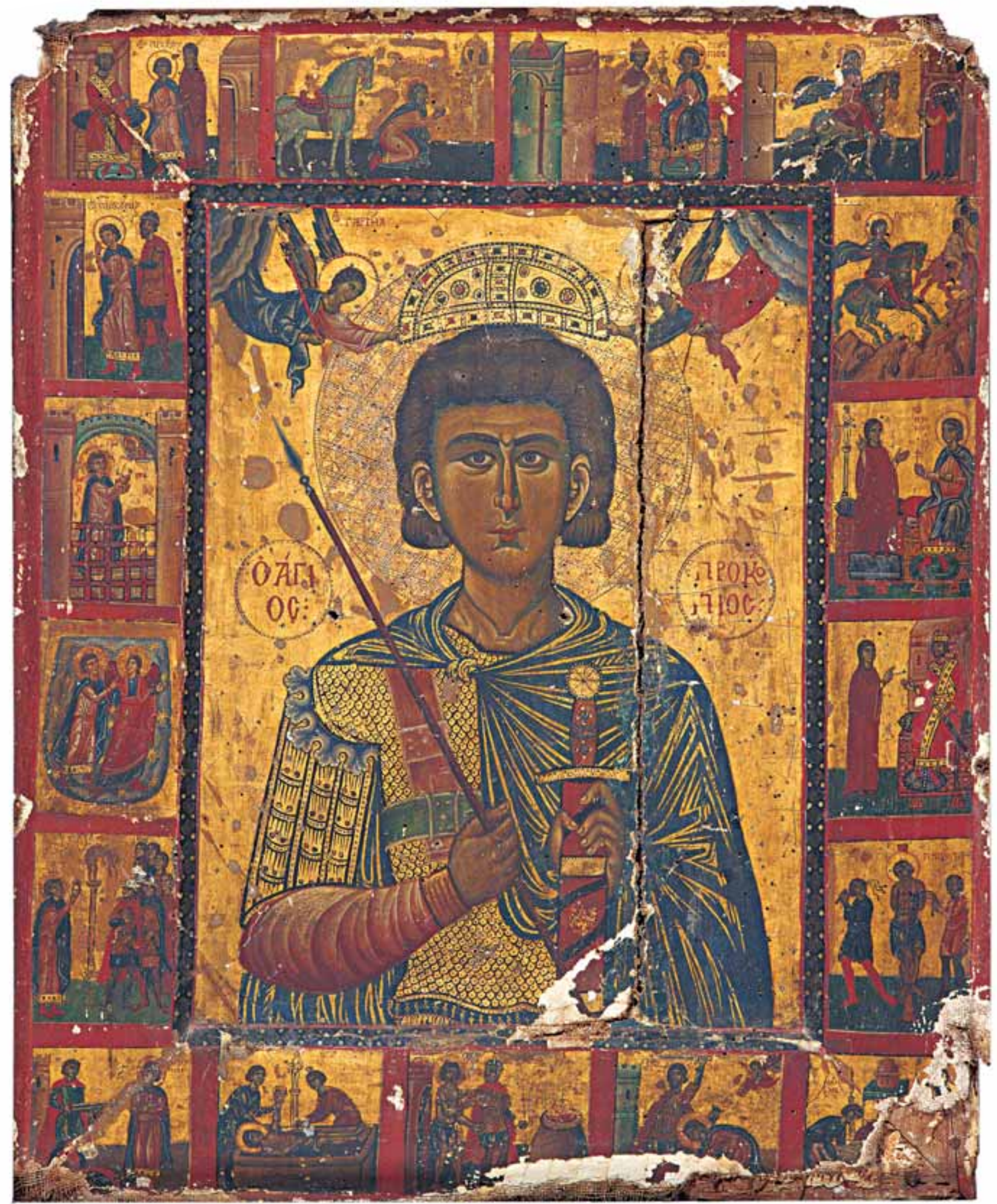

Fig. 18. The vita icon of St Prokopios. Jerusalem, Orthodox Patriarchate. 


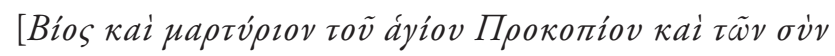
$a v i \tilde{\omega}]$, which has come down to us in the manuscript from the Athonite Vatopedi Monastery, Vatopedi 79, ff. $195^{\mathrm{v}}-207^{\mathrm{x}}$, ed. Papadopoulos-Kerameus ${ }^{35}$ [BHG 1577], also dated to the tenth century.

The life-cycle of St Prokopios on the Jerusalem icon is read in the following sequence: top row, right-hand side, left-hand side, bottom row. The episodes depicted correspond to the following passages in the two Lives.

Top row [1-r]:

1st scene. Neanias receives the title of Duke of Alexandria from the Emperor Diocletian (Halkin $\$ 2$ p. 97.9-38 $=$ Papadopoulos-Kerameus $\$ 2$ p. 3.1-20).

2nd scene. Christ appears to Neanias and shows him the symbol of the Cross with which he will conquer the unbelievers (Halkin $\$ 4$ p. 99-100.1-33 = PapadopoulosKerameus $₫ 3$ p. 4.19-30 and p. 5.1-17).

3rd scene. Neanias receives from the silversmith Markos the cross which he has asked him to make (Halkin $\$ 5$ p. $100-1.1-16=$ Papadopoulos-Kerameus $\$ 4$ p. 5.20-30 and p. 6.1-28).

4th scene. Neanias is told about the infidel raids by the inhabitants of Jerusalem (Halkin $\$ 6$ p. 102.1-17 = Papadopoulos-Kerameus $\$ 5$ p. 7.2-9).

Right-hand side [top to bottom]:

5 th scene. Neanias drives out the infidels (Halkin $\$ 6$ p. 103.14-30 = Papadopoulos-Kerameus $\$ 5$ p. 7.13-20).

6th scene. Neanias defends his faith to his mother Theodosia (Halkin $\$ 7$ p. 103.1-18 = Papadopoulos-Kerameus $\$ 6$ p. 7.24-30 and p. 8, 1-16).

7 th scene. Theodosia betrays her son to Diocletian (Halkin $\$ 7$ p. 104.25-32 = Papadopoulos-Kerameus $\$$ 6 p. 8.17-24).

8th scene. Neanias' ordeal at the stake (Halkin $\$ 9$ p. 106.8-13 = Papadopoulos-Kerameus $₫ 7$ p. 10.12-15).

Left-hand side [top to bottom]:

9th scene. Neanias led to prison (Halkin $\$ 9$ p. 107.2935 = Papadopoulos-Kerameus $\$ 7$ p. 10. 29-30).

10th scene. Christ visits Neanias in prison (10th and 11th scenes, Halkin $\$ 10$ p. 107-9.1-55 = PapadopoulosKerameus $₫ 8$ p. 11.4-29 and p. 12.1-5).

11 th scene. Neanias led by an angel. The creator of the iconographic cycle, inspired by the story in the previous scene with Christ and the angels appearing in the prison, created this scene, probably wishing to show that after his baptism Neanias is introduced by the angel to an alto- gether new state of affairs: sanctity.

12th scene. Prokopios 'dissolves' the idols in the temple (turning them to water) (Halkin $\$ 11$ p. 110.13-17 and $\$$ 12 p. $112.40-4=$ Papadopoulos-Kerameus $\$ 9$ p. 12.28-9, p. 13.1-29 and p. 14.1-28).

Bottom row [1-r]:

13th scene. The soldier Archelaos dies attempting to kill Prokopios (Halkin $\$ 22$ p. 125.1-6 = Papadopoulos-Kerameus $₫ 14$ p. $21.8-15)$.

14th scene. Prokopios' ordeal at the altar (Halkin $\$ 23$ p. $127,24-35=$ Papadopoulos-Kerameus $\$ 16$ p. 23.23-31 and p. 24.1-4).

15 th scene. Prokopios is led to the lighted furnace (Halkin $\$ 24$ p. $128.5-8=$ Papadopoulos-Kerameus $₫ 17$ p. 24.22-30).

16th scene. Beheading of Prokopios (Halkin $\$ 25 \mathrm{p}$. 130.35-7 = Papadopoulos-Kerameus $\$ 19$ p. 27.4-8).

17 th scene. Burial of Prokopios (Halkin $\$ 25$ p. 130.3740 = Papadopoulos-Kerameus $\$ 19$ p. 27.8-9).

6. The vita icon of the Apostle Philip is in the eponymous church in Arsos, Cyprus, where part of the saint's relics are preserved. ${ }^{36}$ This is the largest extant vita icon in the group I am presenting in this study (fig. 19). ${ }^{37}$ The life-cycle around the figure of the apostle is made up of eighteen scenes. The first scene depicts the conversion of Philip by Jesus (fig. 20). After that, the cycle includes Philip's apostolic mission to Asia, on which he was accompanied by his sister Mariamne and the apostle Bartholomew, the martyrdoms of the two apostles and finally Philip's burial (Fig. 21). In ten episodes of the cycle Philip, Bartholomew and Mariamne are accompanied by the kid and the leopard in accordance with Acts VIII (Acta Philipppi, ed. Bonnet $\$ 94-101$ pp. 36-39 and ed. Bovon et. al. $\$ 16-21$ pp. 266-274) (figs 22-25).

The holy personages are distinguished from other figures in the scenes not only by haloes but also by the more elaborate modelling of the faces. The inscriptions on the scenes are misspelt, as is the inscription accompanying the central figure. In the first scene the apostle is accompa-

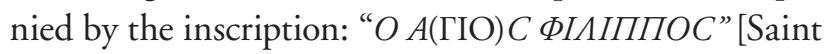
Philip]. This is intentional so that, in the subsequent scenes where he appears with Bartholomew, he can be differentiated from the latter on the basis of what he is wearing in the first scene and by the facial features he is given there. Due to their relatively large dimensions, the 


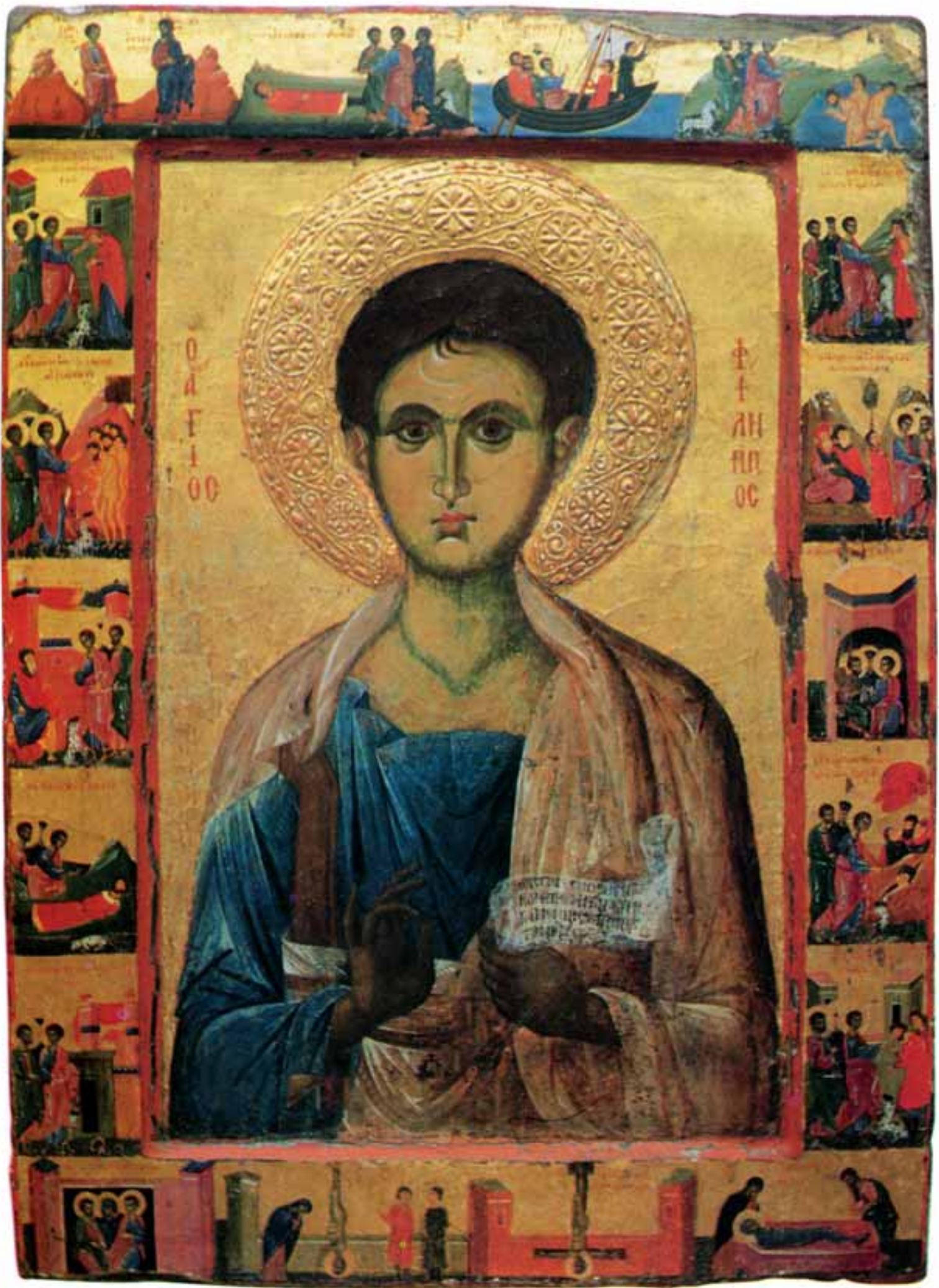

Fig. 19. The vita icon of the Apostle Philip. Cyprus, Arsos, Church of Ayios Filippos. 

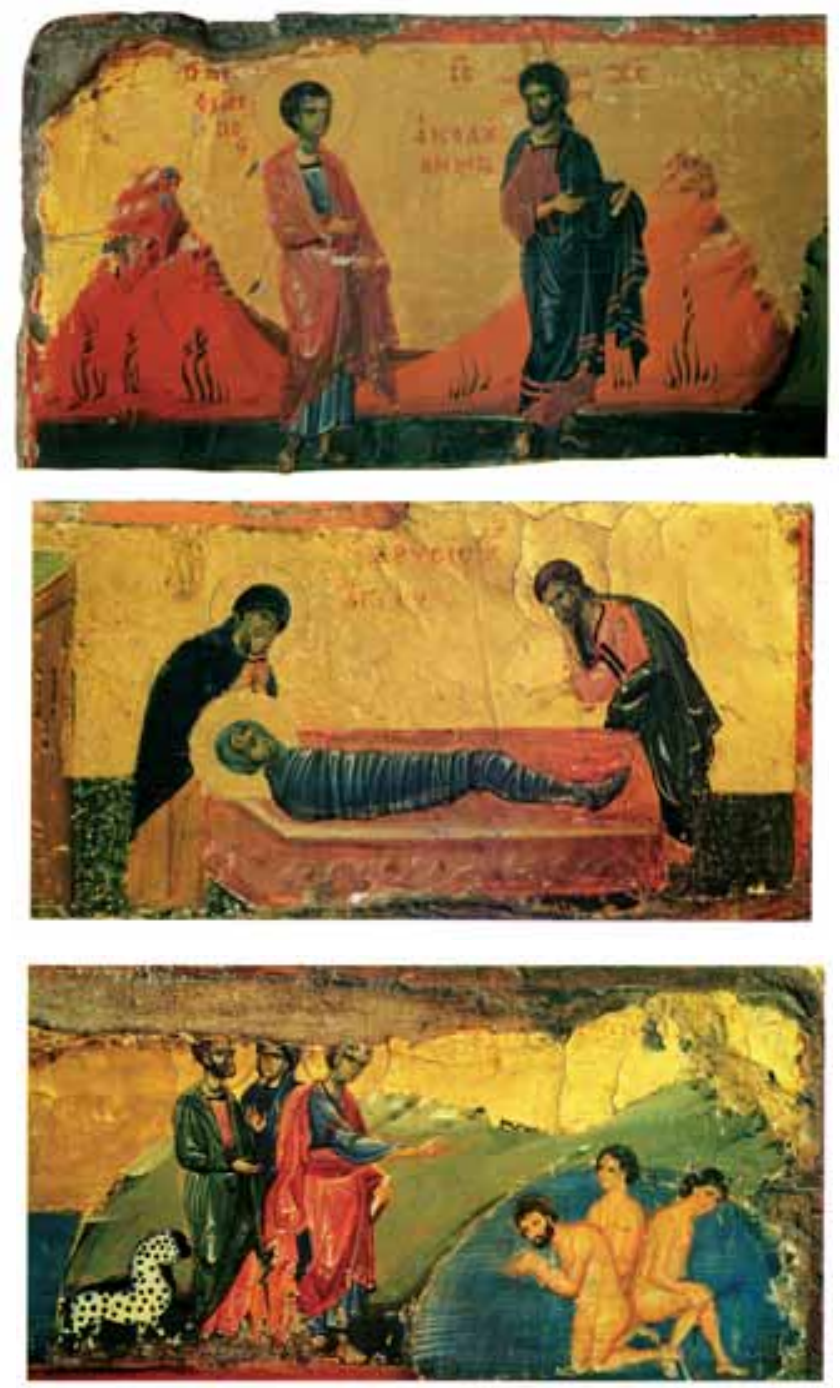

Fig. 20. The conversion of Philip by Jesus. The first scene in the cycle on the vita icon of the Apostle Philip. Cyprus, Arsos, Church of Ayios Filippos.

Fig. 21. The burial of Philip. The eighteenth and final scene in the cycle on the vita icon of the Apostle Philip. Cyprus, Arsos, Church of Ayios Filippos.

Fig. 22. Philip baptizes the ship's crew. The fourth scene in the cycle on the vita icon of the Apostle Philip. Cyprus, Arsos, Church of Ayios Filippos.

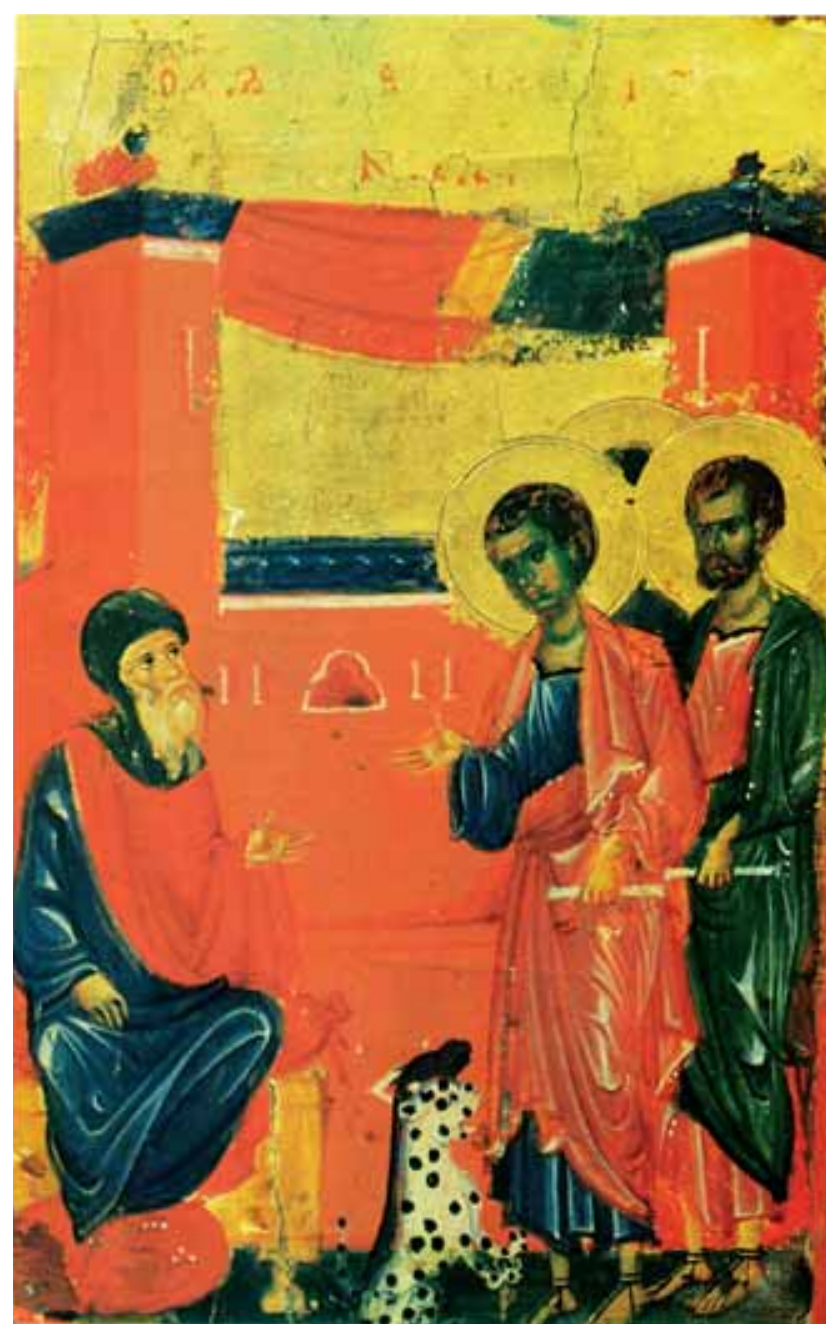

Fig. 23. Philip debating with the Jewish High Priest Annas. The ninth scene in the cycle of the vita icon of the Apostle Philip. Cyprus, Arsos, Church of Ayios Filippos.

scenes surrounding the central figure are better executed than in other vita icons of the period.

The cycle begins on the left-hand side of the top row and finishes at the end (i.e. the right-hand side) of the bottom row. The scenes in the top and bottom rows follow a frieze-like progression, while the scenes on the vertical sides of the frame are arranged in opposing pairs around the central axis of the icon and read from left to right and top to bottom.

It is one of the most problematic cycles, both as regards identifying the episodes, and in terms of overall reading, mainly because the episodes come from the Apocryphal 


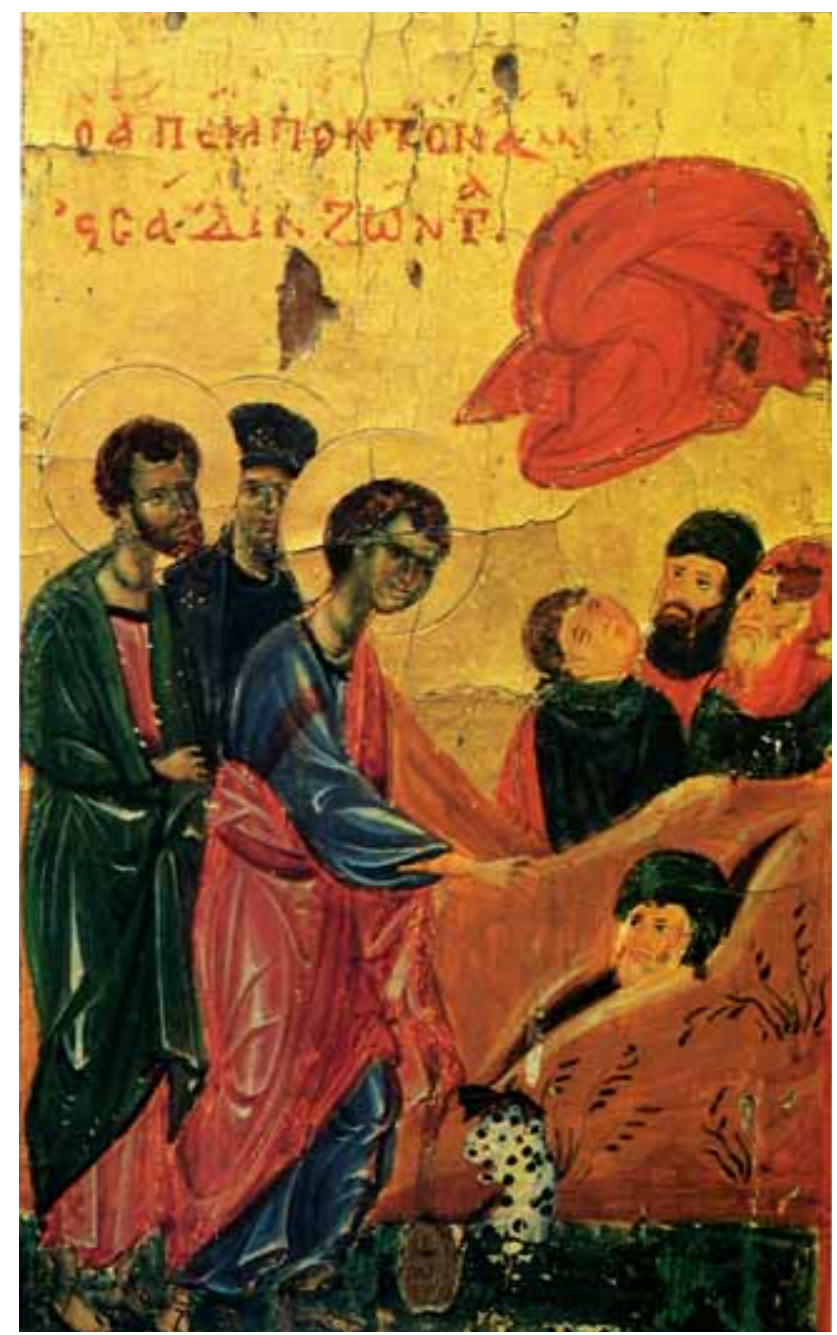

Fig. 24. Philip traps the Jewish High Priest Annas in the earth and then plunges him into the underworld. The twelfth scene on the vita icon of the Apostle Philip. Cyprus, Arsos, Church of Ayios Filippos.

Acts of Philip, but the time sequence they follow in the icon is completely different from that in the Acts.

The solution to the problem of how to read the cycle lies in the Abridged Version of the Apocryphal Acts of the Apostle contained in the eleventh-century codex Mosquensis 161 (Vladimir 379) and in the fourteenthcentury Par. Gr. 1551 [BHG 1528], partly edited by M. Bonnet, entitled: "On the Life and Miracles of the Martyr and Saint and celebrated Apostle Philip, one of the twelve

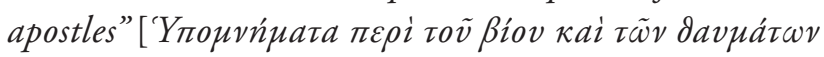

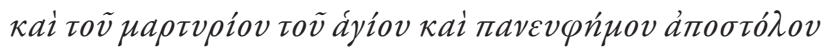

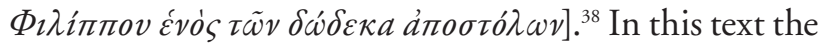

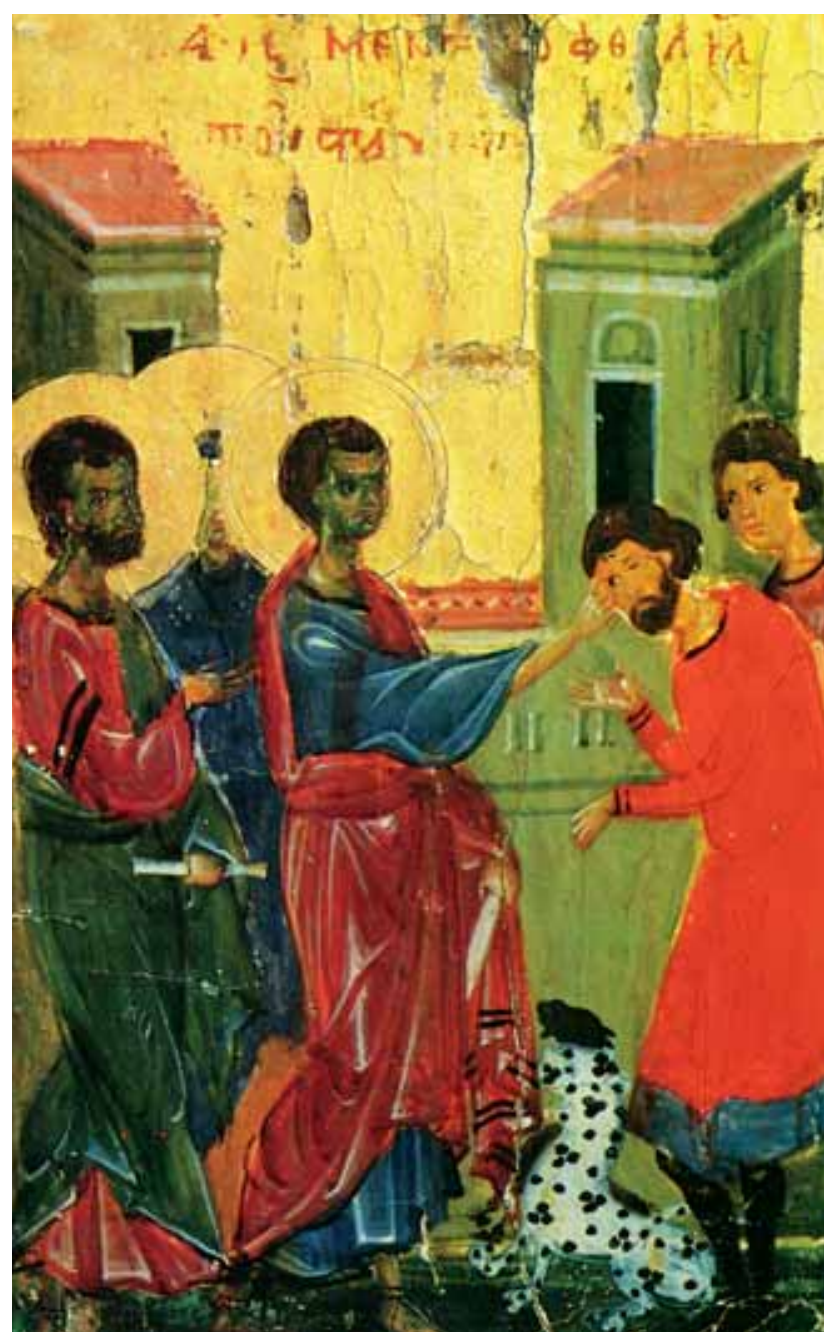

Fig. 25. Philip heals the blind Stachys. The fourteenth scene in the cycle on the vita icon of the Apostle Philip. Cyprus, Arsos, Church of Ayios Filippos.

events which have been selected follow a different order from that in the original text of the Apocryphal Acts; and this sequence corresponds exactly with the order in which the episodes are arranged in the cycle on the vita icon. ${ }^{39}$

It is also worth noting that, while in the text the narrative ends with the burial of Philip followed by the martyrdom of Bartholomew, the artist deliberately inverted the order of the last two episodes, thus ensuring that the cycle would end with the protagonist of the cycle, Philip. And in the last scene the apostle is depicted bound with bands of a dark blue colour and not white. This corresponds with the text, which mentions that he asked to be bound not in 
white, like Christ, but in Syrian (blue) linen (fig. 21).

The episodes in the cycle of the Apostle Philip on the Arsos icon correspond to the following passages from the manuscript Par. Gr. 1551 (the text of the Moscow manuscript is unpublished).

Top row [1-r]:

1st scene. Philip is converted by Jesus ${ }^{40}$ (Bonnet p. 91.67) (fig. 20).

2nd scene. Philip raises the dead son of the Galilean widow $^{41}$ (Bonnet p. 92.3-9).

3rd scene. Philip saves the ship from the storm during the voyage to Azotos $^{42}$ (Bonnet p. 92.21-35).

4th scene. Philip baptizes the ship's crew ${ }^{43}$ (Bonnet p. 92.38-40) (fig. 22).

Vertical sides:

Left, 5th scene. Philip heals the leprosy on Theokleia's face in Azotos $^{44}$ (Bonnet p. 93.15-19).

Right, 6th scene. Philip heals the paralysed hand of the servant of Ireos in Nikatera ${ }^{45}$ (Bonnet p. 93.40-2).

Left, 7 th scene. Philip heals the demoniacs ${ }^{46}$ (Bonnet p. 95.12-21).

Right, 8th scene. Philip, Bartholomew and Mariamne are persecuted by the Jews ${ }^{47}$ (Bonnet p. 95.32-8).

Left, 9th scene. Philip speaking with the Chief Priest Annas $^{48}$ (Bonnet p. 96.6-45) (fig. 23).

Right, 10th scene. Philip, Bartholomew and Mariamne are imprisoned by the Jews ${ }^{49}$ (Bonnet p. 95.32-8).

Left, 11th scene. Philip raises the dead $\operatorname{man}^{51}$ (Bonnet p. 98.9-12, 28-30).

Right, 12th scene. The burying of the Jewish Chief Priest Annas in the earth and his final plunging into the underworld by Philip ${ }^{50}$ (Bonnet p. 98.13-28) (fig. 24).

Left, 13th scene. Philip, Bartholomew and Mariamne enter Hierapolis (Ophioryme) ${ }^{52}$ (Acta Philippi XIII, eds Bovon et. al. $\$ 3$ p. 313.1-4).

Right, 14th scene. Philip heals the eyes of the believer Stachys in Hierapolis ${ }^{53}$ (Acta Philippi XIV, eds Bovon et. al. \$6 p. 327.1-21) (fig. 25).

Bottom row [1-r]:

15th scene. Imprisonment of Philip, Bartholomew and Mariamne in the Temple of the Viper in Hierapolis ${ }^{54}$ (Bonnet $\$ 122[16]$ pp. 50-51).

16th scene. Martyrdom of Philip 55 (Bonnet $\$ 125$ pp. 54-55 and $\$ 140$ p. 73).

17 th scene. Crucifixion of Bartholomew ${ }^{56}$ (Bonnet $\$$ 137 p. 69). 18th scene. Burial of Philip ${ }^{57}$ (Bonnet $\$ 146$ pp. 87-88) (fig. 21).

7. The vita icon of St Marina comes from the church dedicated to St Marina in Kyperounda, Cyprus ${ }^{58}$ (fig. 26). According to the dedicatory inscription on the lower righthand side of the central panel by St Marina's feet, the icon was made on the instructions of a monk called Markos.

The life-cycle around the central figure of the saint contains twelve episodes from her life. The narration begins in the top left-hand corner of the frame with the saint's meeting with the governor Olybrios, continuing across the top and down the right-hand side, then down the left, finishing at the right-hand end of the bottom row with the beheading of the saint. The four episodes in the cycle which take place in the prison and depict the appearance of the demon and his downfall (scenes 5, 6, 7 and 8) are not included in the saint's Life written by Niketas David the Paphlagonian in the tenth century, ${ }^{59}$ nor in the text of the Life contained in the eleventh-century imperial Menologion. ${ }^{60}$ However, these episodes are included in the Life entitled "Martyrion of the

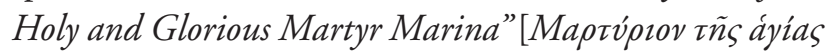

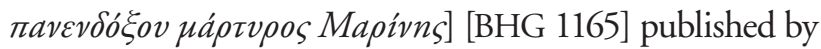
H. Usener. ${ }^{61}$ The twelve episodes of the life-cycle of St Marina correspond to the following passages from this Life:

Top row [l-r]:

1st scene. The meeting between Marina and the governor Olybrios (Usener p. 17.4-16).

2nd scene. Marina before Olybrios ${ }^{62}$ (Usener p. 18.3419.10, or p. 19.14-21.12).

3rd scene. The scourging of Marina ${ }^{63}$ (Usener p. 21.1316).

Right-hand side [top to bottom]:

4 th scene. Marina scraped with iron meat-hooks ${ }^{64}$ (Usener p. 22.8-10 or p. 23.23-26).

5 th scene. Marina in prison and the appearance of the dragon (Usener p. 23.36-24.18).

6th scene. Marina emerging from the mouth of the dragon (Usener p. 27.13-15).

Left-hand side [top to bottom]:

7 th scene. The death of the dragon and the appearance of the demon (Usener p. 27.16-19).

8 th scene. The demon is denounced and annihilated (Usener p. 29.13-30.16 and p. 36.35-40).

9th scene. Marina burned with torches (Usener p. 37.19-21). 


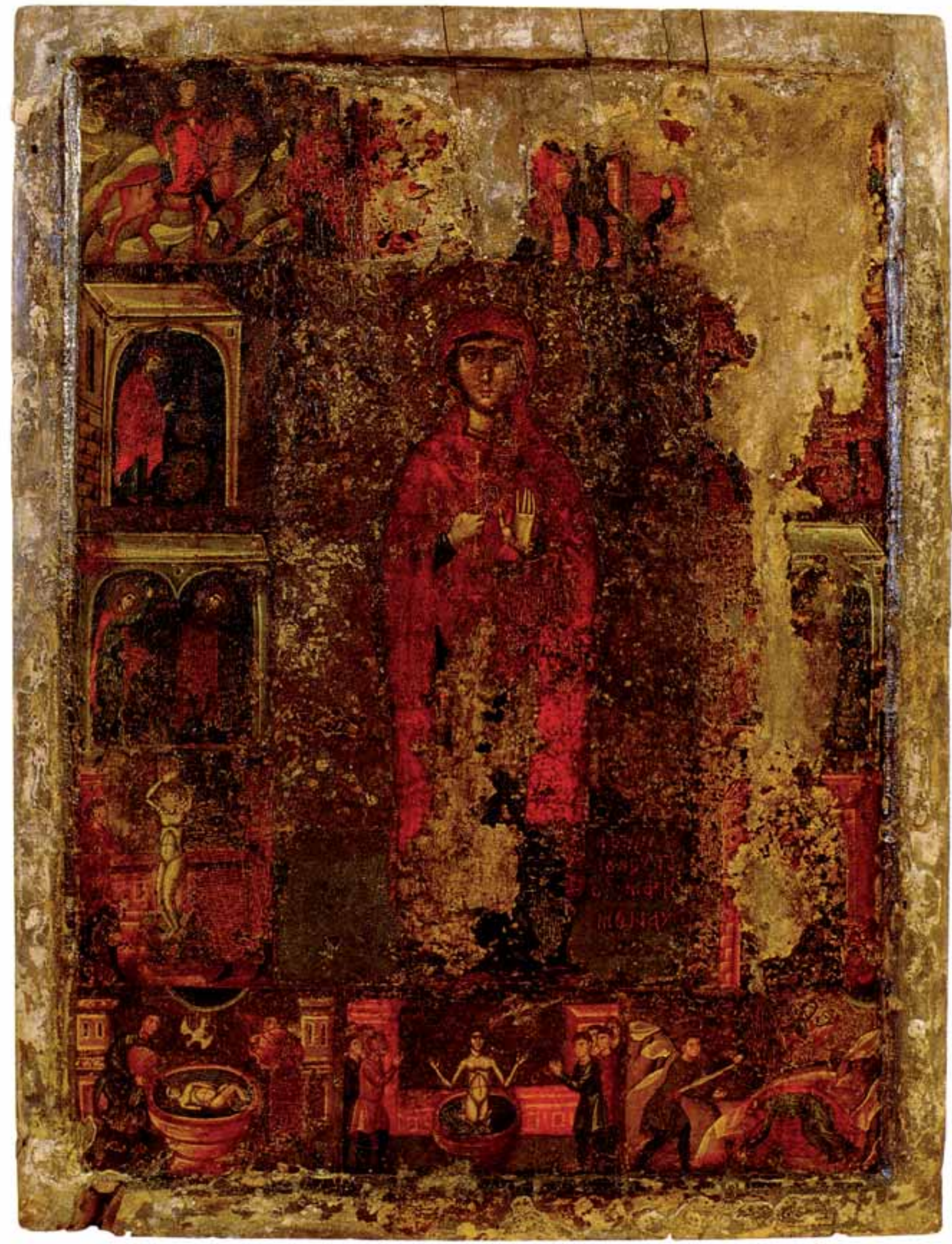

Fig. 26. The vita icon of St Marina from the church of Ayia Marina, Kyperounda. Cyprus, Kyperounda, Holy Cross Museum. 
Bottom row [l-r]:

10th scene. The plunging of Marina into a cauldron full of water and the appearance of the dove (Usener p. 38.3640 and p. 39.3-6).

11th scene. The baptism of Marina and the appearance of the dove (Usener p. 39.6-10).

12th scene. The beheading of Marina (Usener p. 45.3540).

8-9. In the church of St John Lampadistis in Cyprus, which houses the tomb of the eponymous saint ${ }^{65}$ there are two 'crusader' vita icons of the saint dating to the thirteenth century (figs 27, 28). On each of them the life-cycle contains fourteen episodes, ${ }^{66}$ arranged according to the sequence of events found in the saint's synaxarion.

Although the two icons are more or less contemporary, they were not painted by the same artist, nor are we dealing with one work which served as a model for the other, but they consist two distinct artistic conceptions. The difference between the two vita icons lies mainly in the last scenes, in which each painter chose to depict different, if interconnected, episodes relating to the discovery and translation of the saint's relics to the church of St John Lampadistis. One cycle ends with a depiction of this church, founded by the saint's parents (fig. 27), whereas the other ends with the artist, who is painting a picture of the saint in that very church, just as he appears in the central panel of the icon (fig. 29). It represents the 'signature' of the artist, who is shown going towards the saint's church in the preceding scene.

In contrast to the cycles of the saints already described, the life-cycle of St John Lampadistis on both icons lays special emphasis on events after the saint's death: the finding of his holy relics, their translation, and the founding of the church dedicated to his memory. Both cycles lay great emphasis on the holy place in which the saint's relics reside, one depicting the church in the last scene while the other also ends with the church, showing the artist entering and painting the devotional image of the saint.

To date no early manuscript containing a Life of St John Lampadistis has been found. The episodes contained in both life-cycles correspond to a large extent to the extremely brief synaxarion of the saint which has been incorporated in the manuscript akolouthia dating to $1721 .^{67}$ The scenes are read in the following order: top row, righthand side, left-hand side, bottom row.
The cycle on the first icon contains the following scenes (fig. 27). ${ }^{68}$

Top row [1-r]:

1st scene. Birth of John Lampadistis.

2nd scene. John Lampadistis being taught in school.

3rd scene. The wedding of John Lampadistis.

Right-hand side [top to bottom]:

4th scene. John Lampadistis eats the poisoned fish and goes blind.

5th scene. John Lampadistis is led to his parents' home by his father.

6th scene. John Lampadistis gives alms to the poor.

7th scene. The gold-winged eagle appears to John Lampadistis.

Left-hand side [top to bottom]:

8th scene. The saint asks his servant for a bunch of grapes.

9th scene. The saint is reproved by his father because he ate unblessed grapes.

10th scene. The saint sends the servant to put the bunch of grapes on the vine.

11th scene. The koimesis of John Lampadistis.

Bottom row [1-r]:

12th scene. The discovery of John Lampadistis' relics.

13th scene. The translation of the relics of St John Lampadistis.

14th scene. The church of St John Lampadistis.

The cycle on the second icon (fig. 28) ${ }^{69}$ contains the following episodes:

Top row [1-r]:

1st scene. Birth of John Lampadistis.

2nd scene. John Lampadistis led by his father to school.

3rd scene. Wedding of John Lampadistis.

Right-hand side [top to bottom]:

4th scene. John Lampadistis eats the poisoned fish and goes blind.

5th scene. John Lampadistis returns to his parents' home.

6th scene. The gold-winged eagle appears to John Lampadistis.

7th scene. John Lampadistis asks his servant for a bunch of grapes.

Left-hand side [top to bottom]:

8th scene. John Lampadistis is struck by his father for 


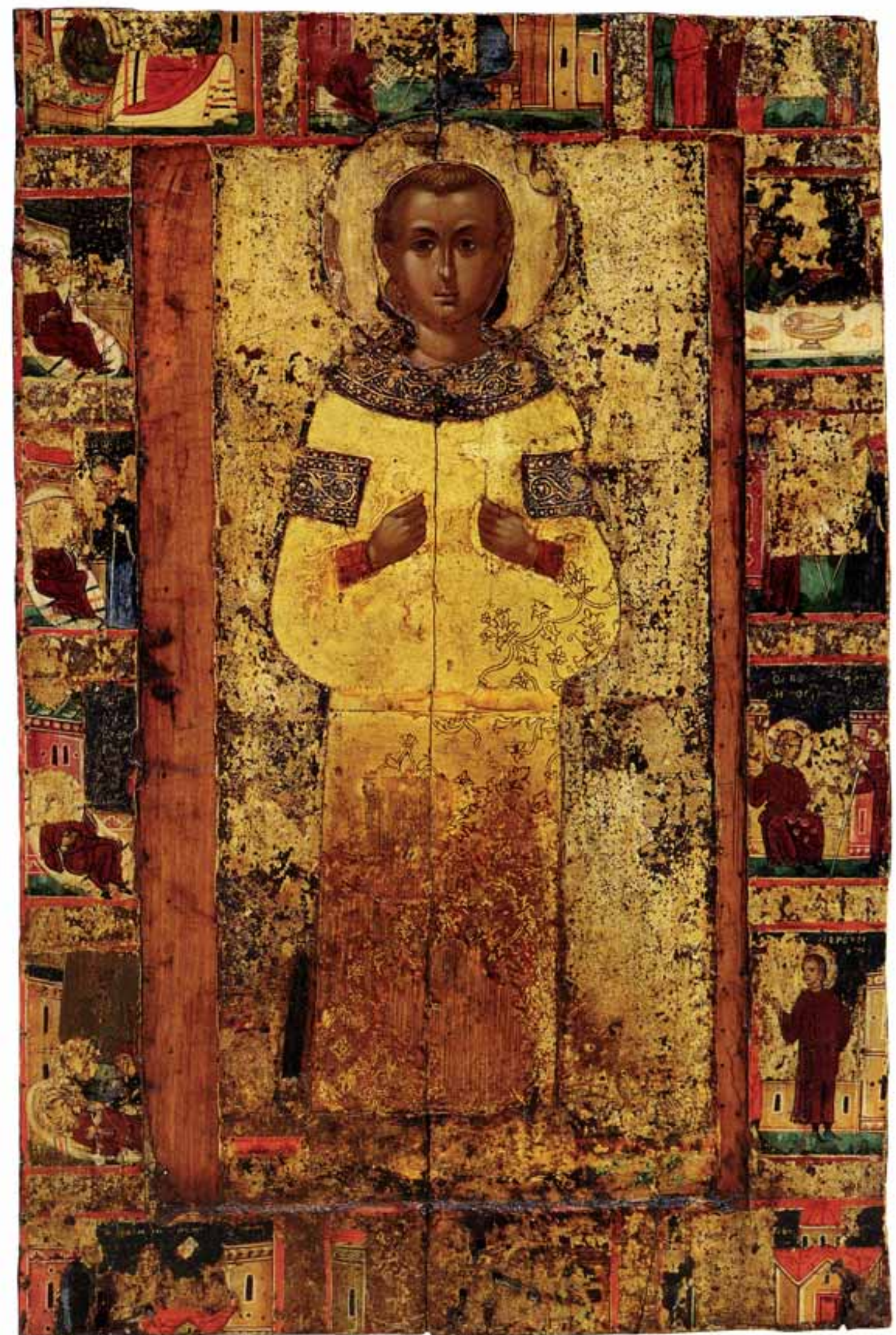

Fig. 27. The vita icon of St John Lampadistis. Cyprus, Kalopanayiotis, Monastery of St John Lampadistis. 


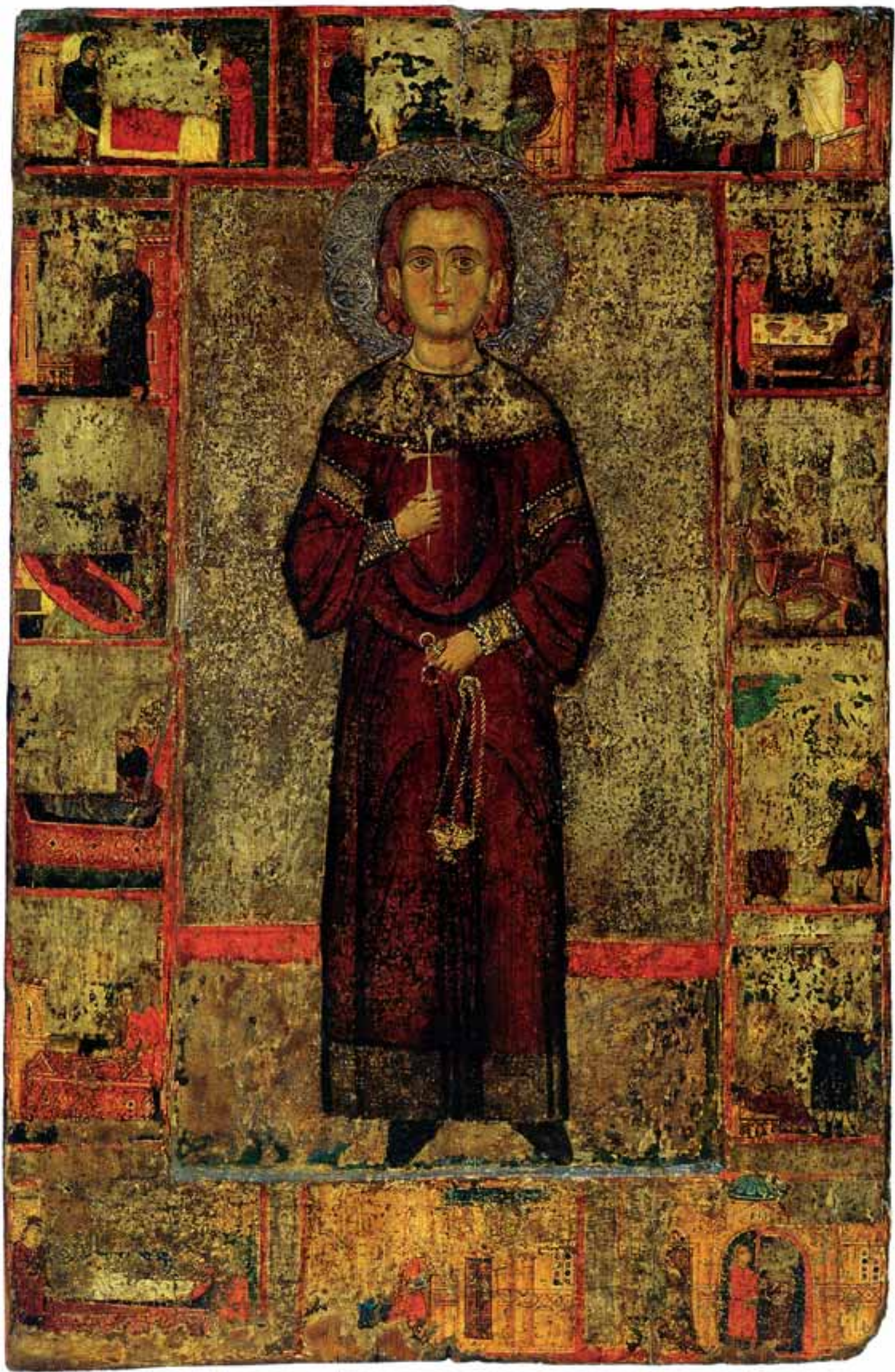

Fig. 28. The vita icon of St John Lampadistis. Cyprus, Kalopanayiotis, Monastery of St John Lampadistis. 


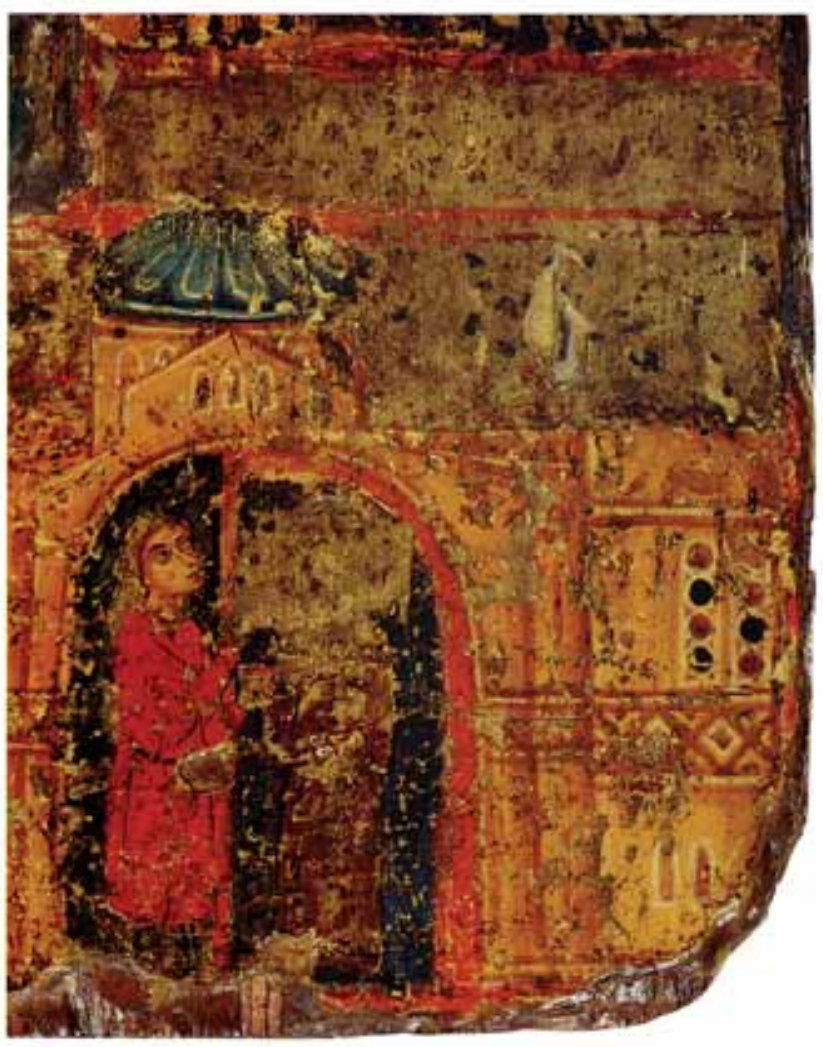

Fig. 29. The artist painting the icon of St John Lampadistis. The last scene in the cycle on the vita icon of St John Lampadistis. Cyprus, Kalopanayiotis, Monastery of St John Lampadistis.

eating unblessed grapes.

9th scene. The re-attachment of the grapes and the death of John Lampadistis.

10th scene. Burial of John Lampadistis.

11th scene. Discovery of the tomb of John Lampadistis.

Bottom row [1-r]:

12th scene. The translation of the relics of John Lampadistis.

13th scene. The painter goes to the church of St John Lampadistis.

14th scene. The artist paints the devotional image of St John Lampadistis in the church dedicated to him (fig. 29).

From studying the icons described above, the following conclusions can be drawn.

Several of the vita icons examined are connected either with the burial place of the saint, ${ }^{70}$ as in the case of St John Lampadistis and St Prokopios, ${ }^{71}$ or with the holy relics of the figure depicted, as in the case of St Catherine ${ }^{72}$ and the Apostle Philip, or with loca sancta, as in the case of the Prophet Moses whose body, according to tradition, was never found.

The life-cycles in the vita icons of St Catherine, St Panteleimon, St George, the Prophet Moses, St Prokopios, the Apostle Philip and St Marina are all based on specific texts. These cycles give visual substance to these texts, highlighting the most important points in the text or, in simple terms, choosing key episodes in the career of each particular saint. As visual narratives they respect the basic requirements of story-telling. The selection and arrangement of the images represent a series of episodes which facilitate an understanding of the relationship between cause and effect over time and describe the transition from an initial to a final state. The time-line is the main axis in the narrative process. But narrative time is translated in the icon into artistic space, as the scenes are assembled on a single surface. Taken as a whole the images serve as a story unfolding, but at the same time each of them is an event of paradigmatic importance.

First of all each of the episodes in the story depicted is connected through the storyline with the previous events and with the subsequent ones. The first image provides the basic reason for what is to follow in the visual narrative. This explains the fact that, apart from the cycles of John Lampadistis and Moses, none of the cycles examined puts the birth of the saint first. Generally speaking a scene is chosen for the starting point which reveals the qualities of the saint or some important event in her/his life. This also constitutes the starting point for the sequence of events which will follow in subsequent scenes, none of which could be explained without the first scene. The life-cycle of St Catherine opens with the scene which depicts her, already a Christian, praying in her living quarters. St George's cycle opens with the scene in which, as a Christian, he distributes his wealth. The Panteleimon cycle begins with the scene in which, as the pagan Pantoleon, the saint meets the Christian Hermolaos who introduces him to the Christian faith. The lifecycle of the Apostle Philip opens with the scene depicting his conversion by Jesus. The Prokopios cycle starts with the scene depicting his acquaintance, as Neanias, with Diocletian and his acceptance of his duties as Duke of Alexandria. This is followed by the vision of the cross and the successful outcome of the battle against the Saracens 


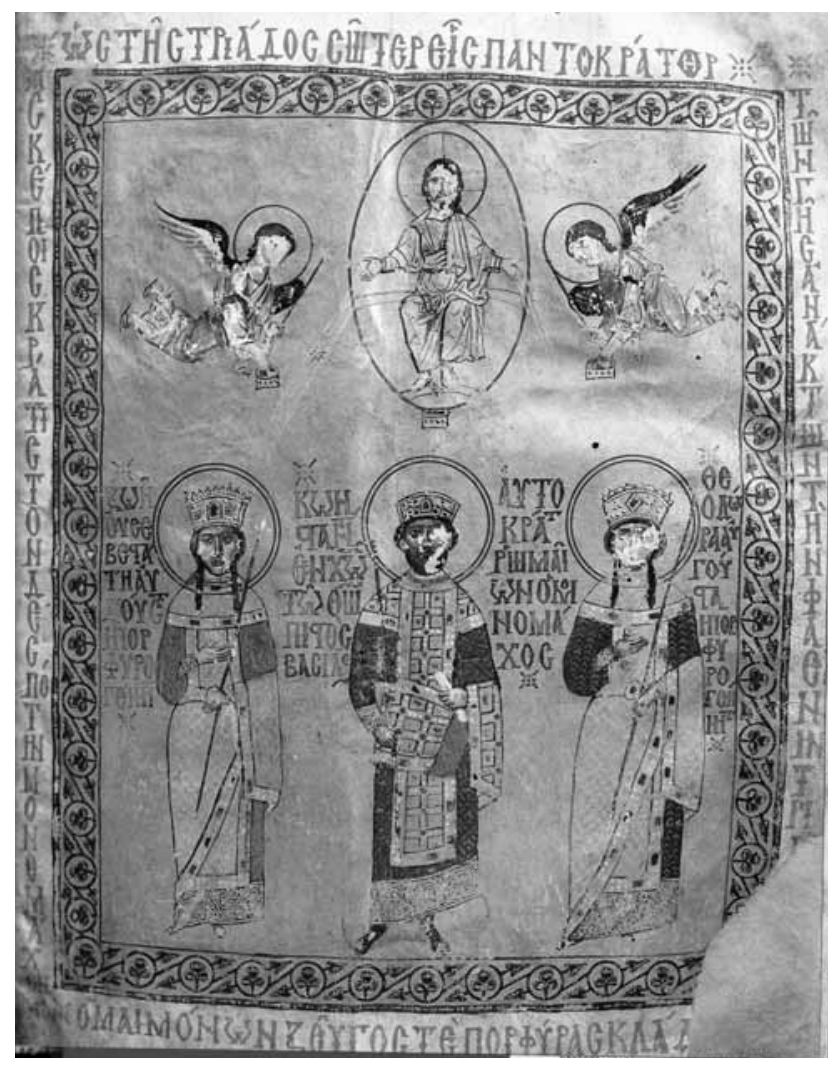

Fig. 30. Codex Sinait. Gr. 364 f. 3r. Sinai, St Catherine’s Monastery.

which is the result of this vision. The Marina cycle opens with the scene depicting the meeting with Olybrios, followed by her imprisonment in the palace and her torments. The Moses cycle begins with the scene depicting his birth which entails his discovery in the Nile by Pharaoh's daughter.

Another important observation is that there are two different ways in which the life-cycle is arranged around the central figure of the saint. The first of these can be seen in the icons of Sts Catherine, George, Prokopios, Marina and John Lampadistis. Here the cycle begins at the left-hand end of the top row, continues down the right-hand side then down the left and finishes at the far end of the bottom row. The second format is found in the vita icons of Moses, Panteleimon and Philip, on which the cycle begins once again at the left-hand end of the top row, but the scenes on the vertical sides are read in pairs from left to right and top to bottom; the cycle ends on the right-hand corner of the bottom row.

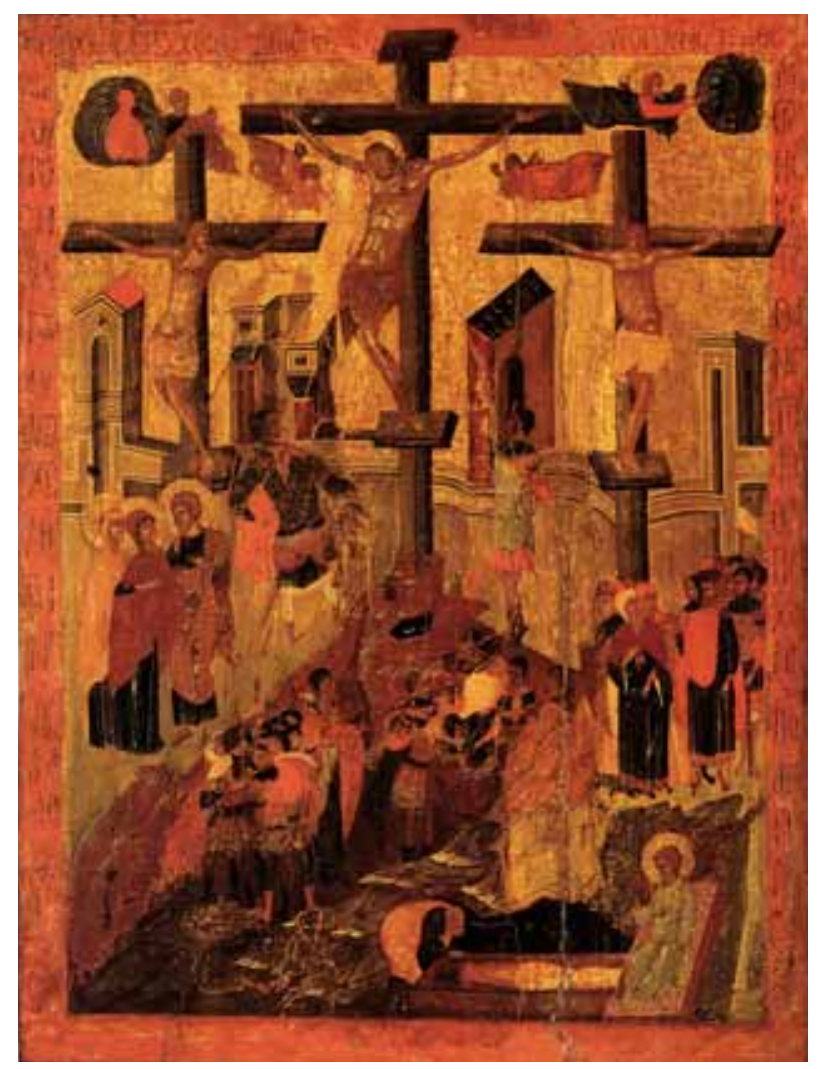

Fig. 31. Icon of the Crucifixion. Moscow, Museum of Cremlin.

As visual narratives the vita icons are directly dependent on texts and they follow the storyline of the narrative. It is natural therefore that the life-cycles, when arranged around the central figure which they are 'commenting on', should follow the way in which inscriptions, verses or commentary are written around a central image or a central text, as a series of extant examples of miniatures and icons make clear. ${ }^{73}$ I will confine myself to just three representative examples of which the first two are related to the first style of reading and the other relates to the second.

The four-line epigram which acts as a kind of commentary on the miniature on f. $3^{\text {r }}$ of Codex Sinait. Gr. 364 (fig. 30 $)^{74}$ showing the figures of the Emperor Constantine Monomachos and the Empresses Zoe and Theodora reads as follows:

Top row:

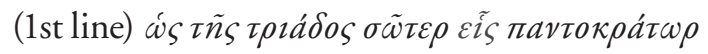
right-hand side:

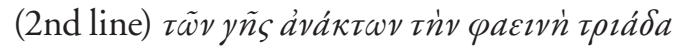




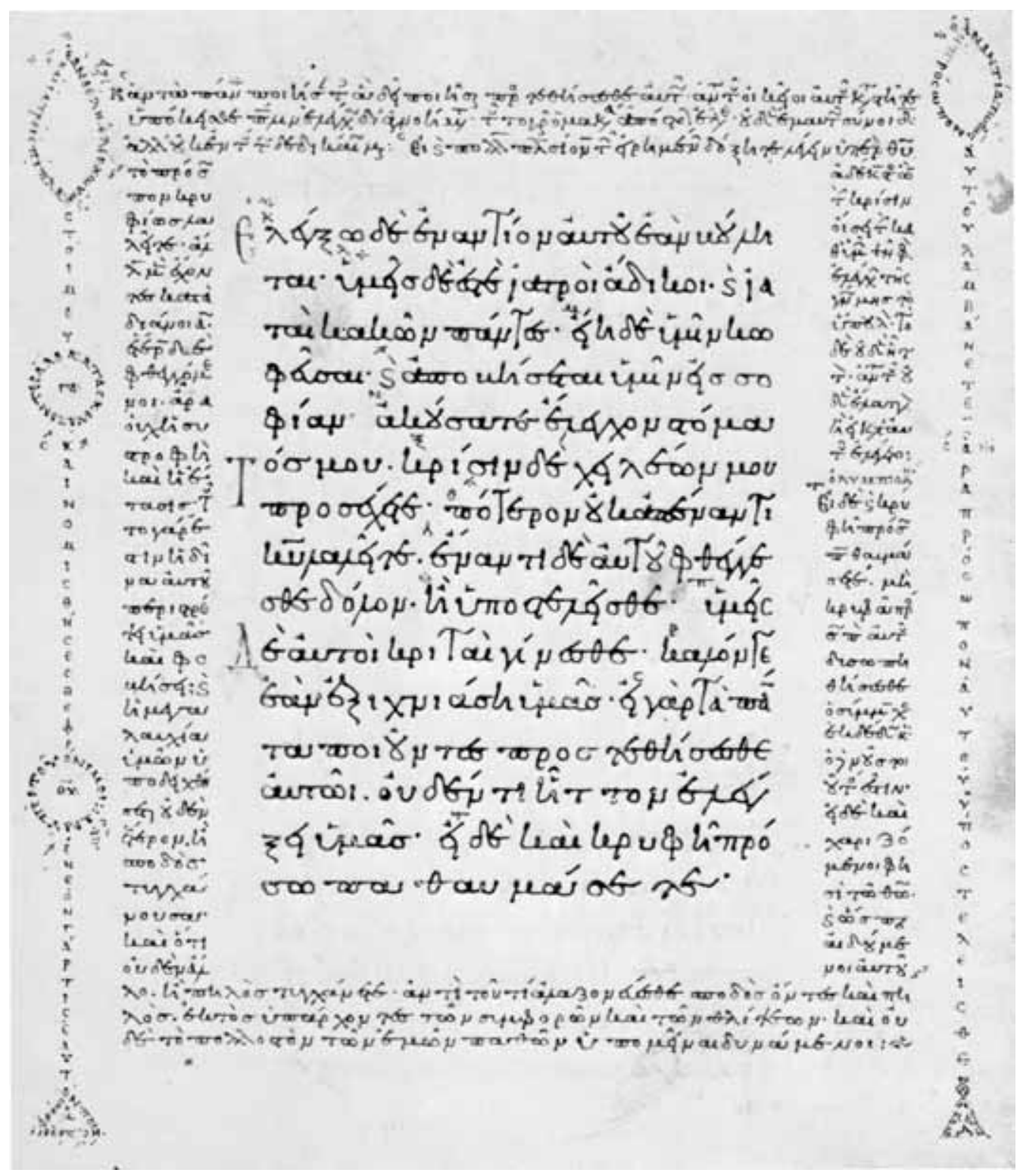

Fig. 32. Codex GKS 6 f. 32v. Copenhagen, Kongelige Bibliotek.

left-hand side:

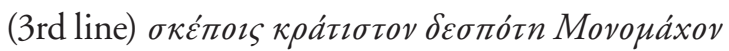
bottom row:

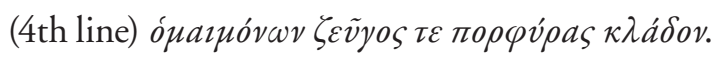

The four lines from an epigram by Theodore Prodromos on the frame of a fifteenth-century Byzantine icon of the Crucifixion (fig. 31$)^{76}$ are arranged as follows:

Top row:

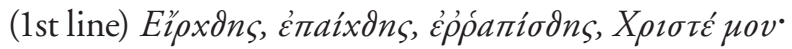

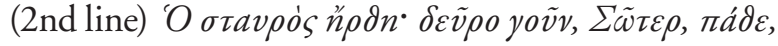

Left-hand side:

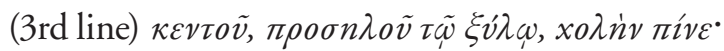

Right-hand side:

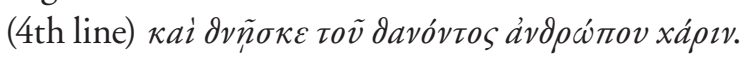

In the famous codex GKS 6 from Copenhagen dated to the second half of the tenth century the commentary around the text of Job on f. $32^{v}$ (fig. 32$)^{75}$ creates a rectangular frame and is read in the following order: across the top row, down the right and then left sides, across the bottom row. 
The nine vita icons which I have been discussing all date to the thirteenth century and, as has been shown, their cycles rely on specific texts. Yet the episodes depicted are not based on the Lives compiled in the mid-tenth century by Niketas David the Paphlagonian ${ }^{77}$ or in the second half of that century by Symeon Metaphrastes. ${ }^{78}$ Bearing in mind that from the eleventh century onwards the Metaphrastian Menologion was the basic reference point for the Lives of the saints, one would expect the vita icons of the thirteenth century to source their material for the pictorial cycles from there. Nevertheless the hagiographical texts on which these cycles on the vita icons presented above rely are generally speaking pre-Metaphrastian and have been less widely copied than the Lives compiled by the Paphlagonian, and a great deal less than those put together by Symeon Metaphrastes.

How can one explain the strange fact that the thirteenth-century vita icons do not follow versions of Lives which had become well-known through 'canonical' texts, but followed older versions of the Lives? I would assert that the thirteenth-century vita icons are not original creations of the period, but copy older vita icons whose cycles are based on pre-Metaphrastic Lives. This conclusion is based on the observation that in some cases, such as the vita icons of Moses and of St Panteleimon, the inscriptions accompanying the scenes do not always correspond to the content of the image. This probably means that the painters of these icons had older models in front of them which they copied, without always being able to identify the scenes correctly, either because there were no inscriptions on their models or because some of them had worn away. In trying to fill in these inscriptions as best they could, they misinterpreted some things.

That vita icons existed before the thirteenth century is also demonstrated by the earliest example we know of to date, the icon of St Marina which comes from the eponymous church in Filousa in Cyprus (fig. 33). ${ }^{79}$ The life-cycle is arranged around three sides of the icon and must have contained nine scenes altogether: three on the top row, and three on each of the two sides. Nowadays only the three scenes on the left remain. On the basis of their stylistic characteristics, the icon can be dated to the second half of the eleventh century.

Given all this evidence the first appearance of vita icons

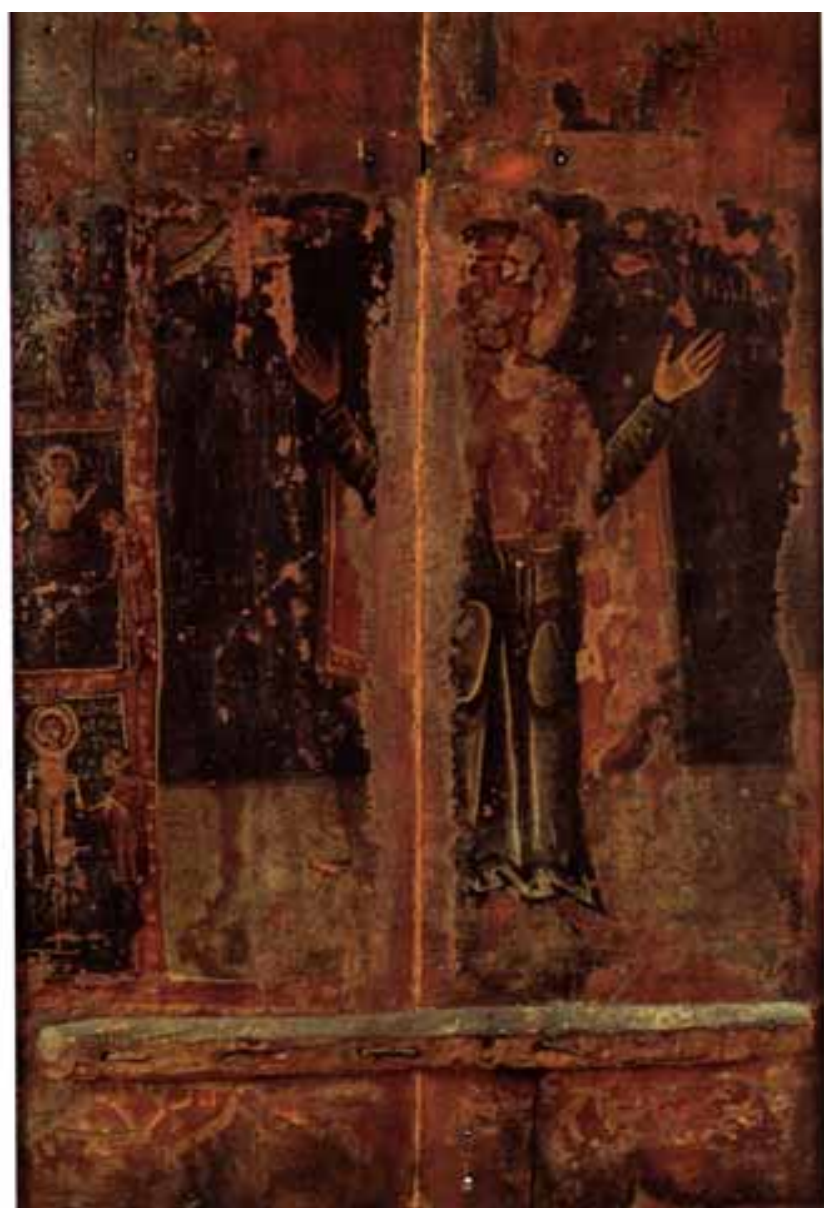

Fig. 33. The vita icon of St Marina from the church of Ayia Marina in Filousa, Cyprus. Cyprus, Paphos, Byzantine Museum of Paphos Cathedral.

should be dated to the tenth century at the latest. Actually the format of these icons is known since the Roman era. ${ }^{80}$

The vita icons' dependence on specific texts and the way in which they are read corresponds to the point made by E. Gombrich, who considered that while the image alone cannot tell the viewer a story they have never heard before, it is extraordinarily well suited to reminding them of stories they have heard. ${ }^{81}$

Titos Papamastorakis

Associate Professor of Byzantine Art

University of Aegean

titosep@yahoo.gr 


\section{Notes}

1. D. Mouriki, Icons from the 12th to the 15th Century, in: K. Manafis (ed.), Sinai: Treasuries of the Monastery of Saint Catherine (Athens 1990) 115-16; H. C. Evans - W. D. Wixom (eds), The Glory of Byzantium (exhibition catalogue, The Metropolitan Museum of Art, New York 1997) 379 no. 249 (N. Patterson-Ševčenko); N. Patterson-Ševčenko, The Vita Icon and the Painter as Hagiographer, DOP 53 (1999) 150-51.

2. G. Sotiriou - M. Sotiriou, Icônes du Mont Sinai (Athens 1956-1958) 148-49; Mouriki (op. cit.) 115-16; PattersonŠevčenko (op. cit.) 151.

3. See Patterson-Ševčenko (n. 1) 150-51, who considers that the vita icons in the East "had no obvious connection to any particular sanctuary or to the saint's relics".

4. On narrativity in medieval art see the following articles: H. Kessler, Pictorial Narrative and Church Mission in SixthCentury Gaul, in: H. Kesller - M. Simpson (eds), Pictorial Narrative in Antiquity and the Middle Ages, Studies in the History of Art 16, Center for Advanced Study in the Visual Arts (= Symposium Series IV, Washington D.C. 1985) 75-91; H. Belting, The New Role of Narrative in Public Painting of the Trecento: Historia and Allegory, ibid. 151-68; W. Tronzo, The Prestige of Saint Peter's: Observations on the Function of Monumental Narrative Cycles in Italy, ibid. 93-112; H. Kessler, Reading Ancient and Medieval Art, Word and Image 5.1 (1989) 1; see also M. Aronberg Lavin, The Place of Narrative. Mural Decoration in Italian Churches, 431-1600 (Chicago 1990) esp. 1-12.

5. See the important book by W. Martin, Recent Theories of Narrative (Ithaca 1986); also P. Ricoeur, Time and Narrative 1-3 (Chicago 1984-1988).

6. On the group of vita icons from the thirteenth century, see the article by Patterson-Ševčenko (n. 1) 150-51. The list of icons which Patterson-Ševčenko has assembled does not include the vita icons of St George from Sinai or St Prokopios from Jerusalem, St Marina from Kyperounda or of the Apostle Philip and the first icon of St John Lampadistis from the eponymous churches in Cyprus, all of which are examined in this article. The St George icon was excluded because it was thought to be a work of the fifteenth century and the others had not then been cleaned and published.

7. The icon measures $75.3 \times 51.4 \mathrm{~cm}$. On the icon and its dating to the late twelfth or early thirteenth century, see Sotiriou (n. 2) 147-49; K. Weitzmann, Icon Programs of the 12th and 13th Centuries at Sinai, DChAE 12 (1984-1985) 95; Mouriki (n. 1) 115 fig. 46; H. C. Evans (ed.), Byzantium: Faith and Power (1261-1557) (exhibition catalogue, The Metropolitan Museum of Art, New York 2004) 341-43 no. 201 (N. Patterson-Ševčenko) which gives the earlier bibliography.

8. Sotiriou (n. 2) 148; Byzantium: Faith and Power (op. cit.).

9. Sotiriou (n. 2) 149; Mouriki (n. 1) 115.

10. Sotiriou (n. 2) 149.
11. See J. Viteau, Passions des saints Ecaterine et Pierre d' Alexandrie Barbara et Anysia (Paris 1897) 45.

12. Ibid. 41-65; according to ibid. 2, Symeon Metaphrastes repeats this Life with minor variations; the Life which Metaphrastes compiled is published in: PG 116 col. 275-302.

13. A. Drandaki, Through Pilgrims' Eyes: Mt Sinai in Pilgrim Narratives of the Thirteenth and Fourteenth Centuries, DChAE 27 (2006) 501-03.

14. The icon measures $142 \times 90 \mathrm{~cm}$. The icon has been comprehensively studied in D. Mouriki, A Moses Cycle on a Sinai Icon of the Early Thirteenth Century, in: C. Moss - K. Kiefer (eds), Byzantine East, Latin West. Art-Historical Studies in Honor of Kurt Weitzmann (Princeton 1995) 531-46 figs 1-16, which gives a detailed description of the cycle and dates the icon to the early thirteenth century.

15. Mouriki (n. 14) 535-36.

16. Mouriki (n. 14) 535, 539.

17. According to Mouriki (n. 14) 538-39.

18. Weitzmann (n. 7) 101.

19. The icon measures $102 \times 72 \mathrm{~cm}$ : ibid. 101-02. The inscriptions were published by Mouriki (n. 1) 76. On the icon and the life-cycles of St Panteleimon in Byzantine wall painting, see

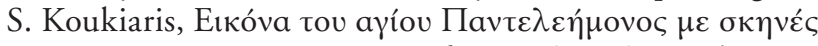

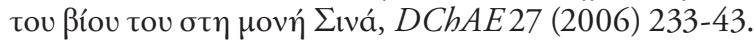

20. Mouriki (n. 1) 116 n. 77; The Glory of Byzantium (n. 1) 379 no. 249 (N. Patterson-Ševčenko).

21. Mouriki (n. 1) 116 n. 77; The Glory of Byzantium (n. 1) 379 no. 249 (N. Patterson-Ševčenko).

22. Mouriki (n. 1) 116.

23. See B. Latysev, Hagiographica graeca inedita, Mémoires de l'Académie Impériale des Sciences de St. Petersbourg, series 12.2 (1914) IV, 40-53.

24. See L. Sternbach, Ioannes Geometrae carmen de S. Panteleemone, Dissertationes classis philologicae Academiae litterarum Cracoviensis 16 (1892) 218-303; Sternbach used the 11th-12th-century Paris Cod. Gr. 690 (BHG 1415) for his edition; on Geometres' encomium see K. Demoen, John Geometres' Iambic Life of Saint Panteleemon. Text, Genre and Metaphrastic Style, in: Philomathestatos, Studies in Greek and Byzantine Texts presented to J. Noret (Leuven 2004) 165-84, esp. 166-67.

25. The icon measures $44 \times 33.5 \mathrm{~cm}$; on this icon see Sotiriou (n. 2) 154-5; also T. Mark-Weiner, Narrative Cycles of the Life of St. George in Byzantine Art (Ann Arbor 1982) 81-82.

26. Sotiriou (n. 2); D. Mouriki, Portraits de donateurs et invocations sur les icônes du XIIIe siecle au Sinaï, in: A. Guillou (ed.), Modes de vie et modes de pensée à Byzance, Études Balkaniques 2 (1995) 115. 
27. K. Krumbacher, Der heilige Georg in der griechischen Überlieferung (München 1911) 41-58.

28. Edition AASS Aprilis III, IX-XV; the epistolary prologue is published by Krumbacher (n. 27) 181-82; see S. Paschali-

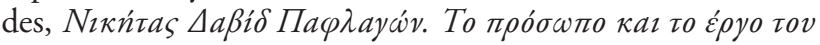
(Thessaloniki 1999) 187-91.

\section{PG 115 col. 141-62.}

30. Krumbacher (n. 27) 59-83.

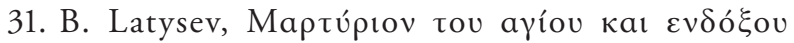

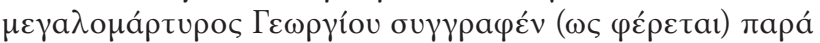

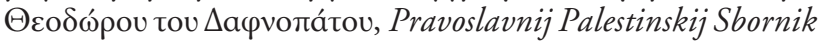
59 (1911) 1-36.

32. The icon measures $75 \times 60 \mathrm{~cm}$ : M. Garidis, Icônes du XIIIe et du XIVe siècle dans l'aire du Patriarcat de Jérusalem, in: Evuvxía, Mélanges offerts à Hélène Ahrweiler (Paris 1998)

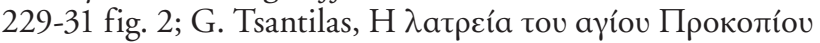

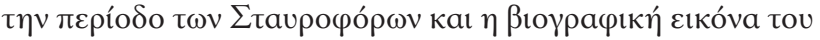

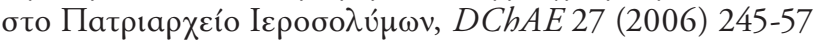
figs 2-6, in which the icon is dated to the period 1280-1290 and classified as one of the crusader icons produced in Acre.

\section{Ibid. 256.}

34. F. Halkin, Inédits Byzantins d'Ochrida, Candie et Moscou (Brussels 1963) 95-130.

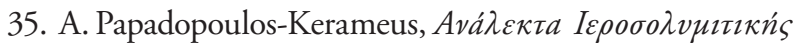

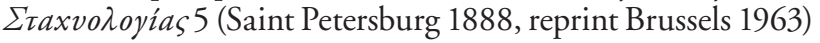
1-27.

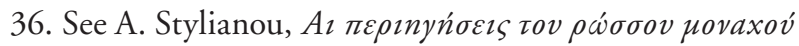

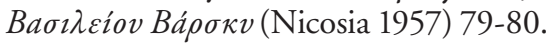

37. The icon measures $150 \times 108 \mathrm{~cm}$; see the book published by the conservators who restored the icon: K. Gerasimou - K.

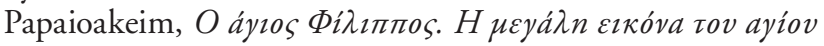

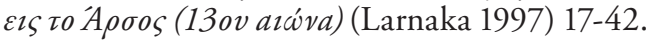

38. Acta Philippi, in: R. Lipsius - M. Bonnet (eds), Acta Apostolorum Apocrypha II.2 (Leipzig 1903, reprint Darmstadt 1959); Fr. Bovon - B. Bouvier - Fr. Amsler (eds), Acta Philippi (Turnhout 1999) XXXVI.

39. See Acta Philippi (n. 38) 91; Bovon - Bouvier - Amsler (n. 38) XXXVI.

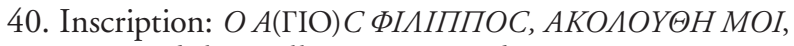
IC XC [Saint Philip, Follow me, Iesus Christos].

41. Inscription: $O A(\Gamma \mathrm{IO}) C A N I C T O N$ TON NEKPON [The Saint raising the dead man].

42. Inscription: $O A(\Gamma \mathrm{IO}) C \triangle I A C \Omega Z O N$ TO ПАION [The Saint saving the ship].

43. Inscription: [OАГІОСВАПТ]IZON[TOYC N]A[YTIKOYC] [The Saint baptizing the sailors].

44. Inscription: $O A(\Gamma \mathrm{IO}) C I \Omega M E N O C$ THC $\Lambda$ I PO $\Theta I C I C$ ГYNAIKOC THN MOPФHN[The Saint healing the face of the woman with leprosy].
45. Inscription: $O A(\Gamma \mathrm{IO}) C I \Omega M E N O C$ THN ПAPA $[$ YTON]

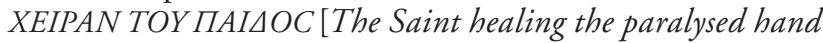
of the slave].

46. Inscription: $O A(\Gamma \mathrm{IO}) C I \Omega M E N O C$ [TOYC] $\triangle E M O N I-$ ZOMENOYC [The Saint healing the demoniacs].

47. Inscription: OI AГIOI YПO TSNEBPAISN $\triangle I O K O M E N O I$ [The Saints pursued by the Jews].

48. Inscription: $O A(\Gamma \mathrm{IO}) C \triangle[\mathrm{IA} \Lambda] E[\Gamma \mathrm{OM}$ NOC META TOY A]NN[A] [The Saint speaking with Anna].

49. Inscription: OI AГIOI EN TH ФYАAKH[The Saints in prison].

50. Inscription: $O A(\Gamma \mathrm{O}) C$ ПЕMПON TON ANN[A] EIC A $\triangle I N Z \Omega N T A$ [The Saint sending Anna to Hell alive].

51. Inscription: $O A(\Gamma \mathrm{IO}) C A N I C T O N[T O N]$ NEKPON [The Saint raising the dead man].

52. Inscription: OI AГIOI HCEPXOMEN[OI] EN TH IЕРАПОАН [The Saints entering Hierapolis]; the serpent worship practised by the citizens of Hierapolis is indicated by the two vipers at the entrance to the town.

53. Inscription: $O A(\Gamma \mathrm{IO}) C I O M E N[\mathrm{OC}$ TOYC] $O \Phi \Theta[\mathrm{A}] \Lambda M O Y C$ TOY CTAX[YOC] [The Saint healing the eyes of Stachys]; the healing of Stachys by the apostle and his sister in the cycle on the Arsos icon (14th scene) quite correctly follows the arrival of the apostles in Hierapolis where they stayed with the blind Stachys, whom Philip cured; the healing of the blind man, Stachys, is the subject of the Fourteenth Act of the Apostle Philip, which is preserved in Xenophon cod. 32, ff. 83v-88v , see Bovon - Bouvier - Amsler (n. 38) 319-29.

54. Inscription: OI A[ГІ]OI EN TH ФYАAKH [The Saints in prison].

55. Inscription: О АГІОС ФІАІППОС [...] [Saint Philip...].

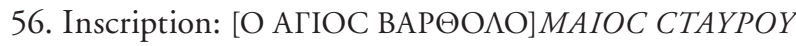
ANAPTSMENOC [Saint Bartholomew hung on the cross].

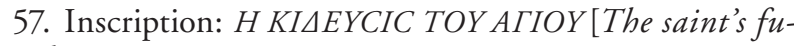
neral].

58. The icon measures $55.5 \times 42 \mathrm{~cm}$; see S. Sophocleous, Icônes de Chypre, Diocèse de Limassol 12e-16e siècle (Nicosia 2006) 195 no. 98 fig. 98.

59. The Life has come down to us in the 16th-17th-century Ms. Grigoriou 7 ( $\Lambda$ 554), $432-44$ and is unpublished; see Paschalides (n. 28) 210-12; I thank my colleague S. Paschalides for bringing this manuscript version of the unpublished text to my attention.

60. V. Latysev, Menologii anonymi byzantini, Saeculi $X$ (Saint Petersburg 1912, reprinted Leipzig 1970) 2, 178-84.

61. H. Usener, Acta S. Marinae et S. Christophori, Festschrift zur fünften Säcularfeier der Carl-Ruprechts-Universität zu Heidelberg (Bonn 1886) 15-47; on the St Marina cycles in

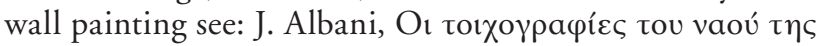

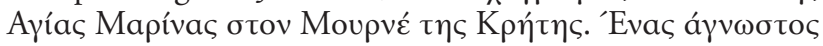




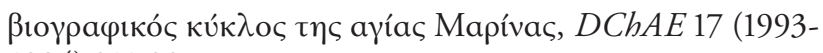
1994) 211-22.

62. Although the scene is quite damaged, Olybrios, seated on a throne on the left, can be made out as can the soldier who is leading Marina towards him.

63. Most of the scene has been lost. On either side parts of the bodies of the two torturers can be made out. Their stance is the same as in other similar martyrdoms.

64. The torturer on the right can be made out, part of the saint's body in the centre and part of the torturer on the left.

65. O. Meinardus, Relics in the Churches and Monasteries of Cyprus, Ostkirchliche Studien 19 (1970) 33.

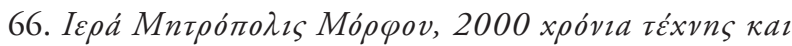
ayıótñoৎ (Nicosia 2000) nos 4-5, 250, 252 (Chr. Chatzichristodoulou); it should be noted that the St John Lampadistis cycle was painted on the arch over his tomb: Chr. Chatzichris-

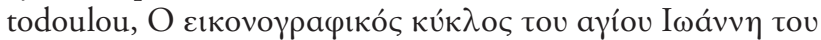

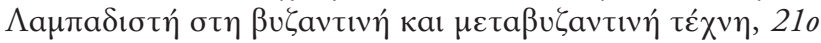

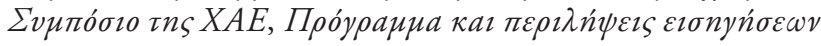

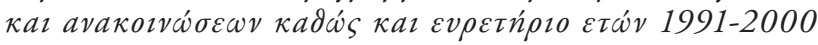
(Athens 2001) 104-05.

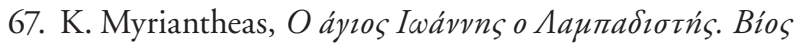

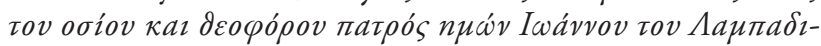

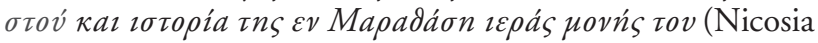
1969) 81-161, esp. 142-43; an earlier akolouthia for the saint was printed in Venice in 1667 and contains an even briefer synaxarion than that in the 1721 manuscript version, ibid. 10506.

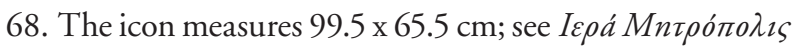

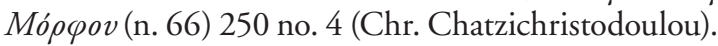

69. The icon measures $115 \times 75 \mathrm{~cm}$; ibid. 252 no. 5 (Chr. Chatzichristodoulou).

70. For a similar placing of vita icons near the tombs of saints in the West, see J. Cannon, Beyond the Limitations of Visual Typology: Reconsidering the Function and Audience of three Vita Panels of Women Saints $c$. 1300, in: V. Schmidt (ed.), Italian Panel Painting of the Duecento and Trecento (= Studies in the History of Art 61, Center for Advanced Study in the Visual Arts, Symposium Papers XXXVIII, Washington D.C. 2002) 291-313.

71. See Tsantilas (n. 32) 256-57.
72. See N. Patterson-Ševčenko, St Catherine of Alexandria and Mount Sinai, in: P. Armstrong (ed.), Ritual and Art: Byzantine Essays for Christopher Walter (London 2005) 129-143; Drandaki (n. 13) 492-93.

73. On the two main ways of reading verses relating to works of art, see E. Follieri, Lordine dei versi in alcuni epigrammi bizantini, Byzantion 34.1 (1964) 447-67.

74. J. Spatharakis, The Portrait in Byzantine Illuminated Manuscripts (Leiden 1976) 100; K. Weitzmann-G. Galavaris. The Monastery of Saint Catherine at Mount Sinai. The Illuminated Greek Manuscript 1: From the Ninth to the Twelfth Century (Princeton 1990) 66.

75. H. Belting - G. Cavallo, Die Bibel des Niketas (Wiesbaden 1979) fig. 15.

76. On this icon, see Vizantija. Balkani. Rus, Ikoni XIII-XV vekov (Moskva 1991) no. 97, though the epigram is incorrectly transcribed; on the epigram, see G. Papagianis, Theodoros Prodromos. Jambische und hexametrische Tetrasticha auf die Haupterzäblungen des Alten und des Neuen Testaments (Wiesbaden 1997) 2, 239-40; both A. Frolow, Quelques inscriptions sur les oeuvres d'art du moyen age, Cahiers Archéologiques 6 (1952) 167 and H. Maguire, Image and Imagination: The Byzantine Epigram as Evidence for Viewer Response (Toronto 1996) 23 , read the verses on the icon incorrectly.

77. Paschalides (n. 28) 152-54 no. 17 (Philip); 187-91 no. 35 (George); 206-08 no. 47 (Prokopios); 210-12 no. 49 (Marina); 215-16 no. 51 (Panteleimon).

78. C. Høgel, Symeon Metaphrastes. Rewriting and Canonization (Copenhagen 2002) 186 (Philip), 188 (Catherine), 201 (George), 203 (Prokopios), 203 (Panteleimon).

79. The icon measures $107.5 \times 72 \mathrm{~cm}$. A. Papageorgiou,

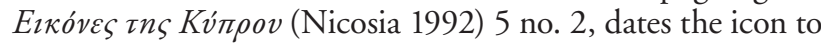
the 8th or 9th century; S. Sophocleous, Icons of Cyprus. 7th20th century (Nicosia 1994) 75 no. 1a, dates it to the 7th or 8th century.

80. See N. Patterson-Ševčenko, The Life of Saint Nicholas in Byzantine Art (Turin 1983) 163; see also S. Zwirn, The Intention of Biographical Narration on Mithraic Cult Images, Word and Image 5.3 (1989) 1-18.

81. E. Gombrich, The Image and the Eye. Further Studies in the Psychology of Pictorial Representation (Cornell 1982) 155-57. 


\section{TITO $\Sigma$ ПАПАМА $Г$ TOРАКН $\Sigma$}

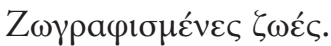

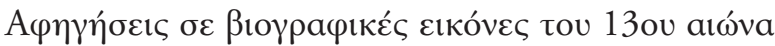

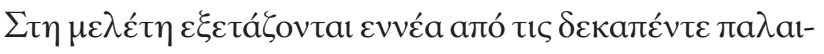

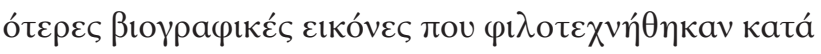

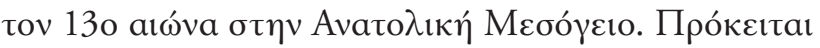

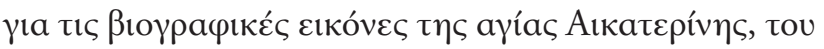

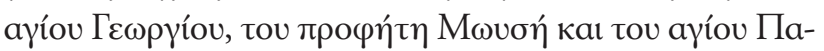

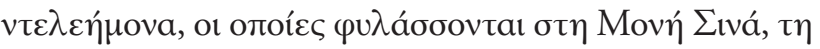

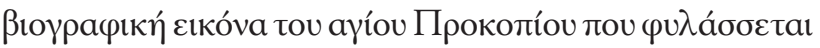

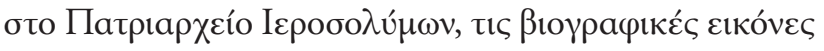

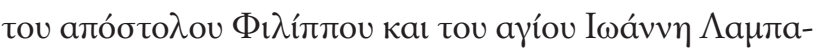

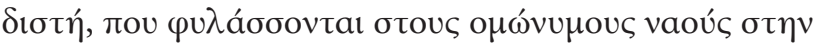

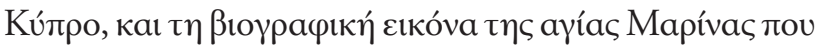

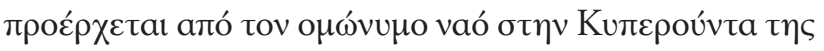

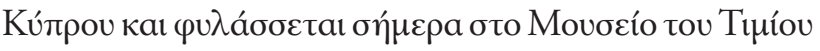

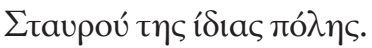

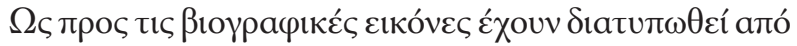

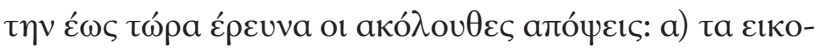

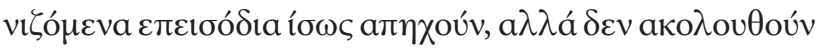

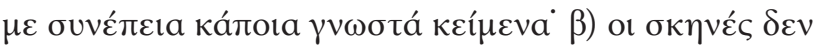

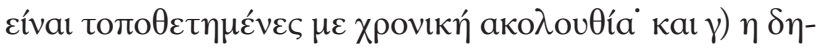

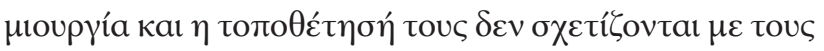

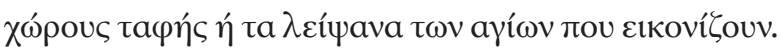

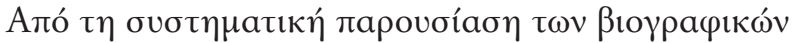

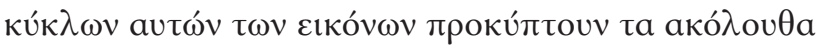
бинлєра́оната:

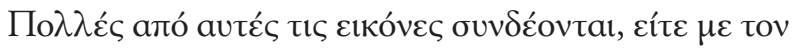

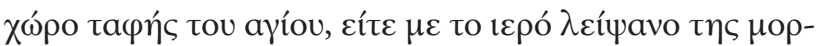

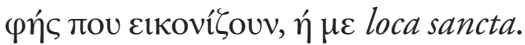

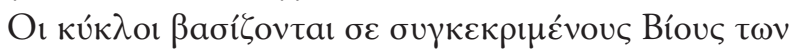

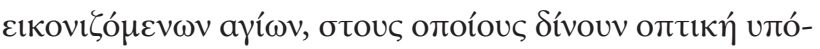

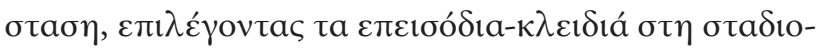

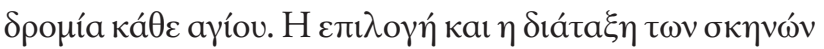
a

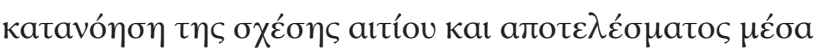

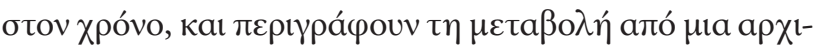

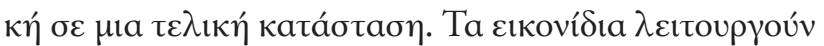

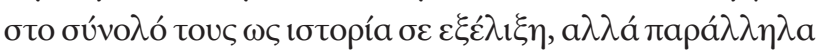

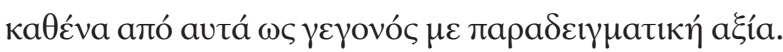

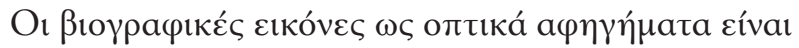

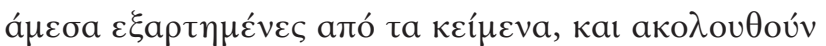

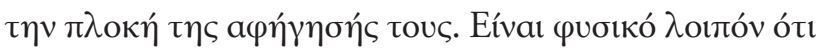

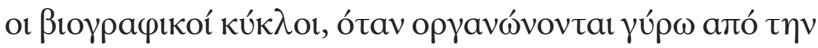

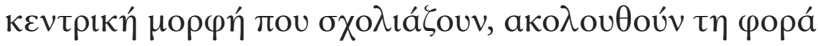

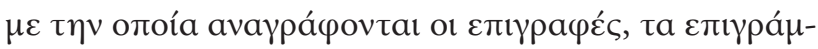

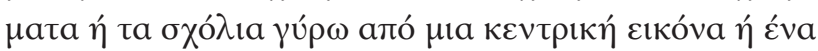

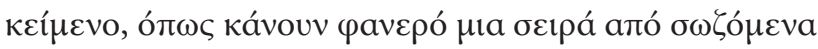

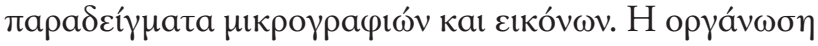

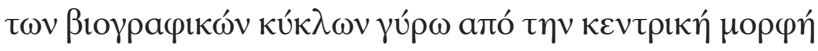

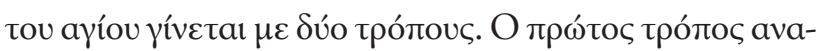

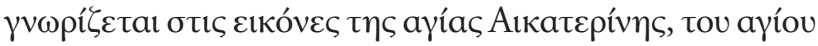

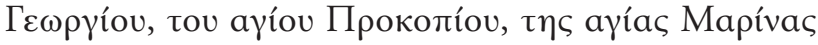

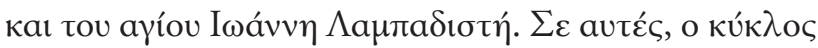

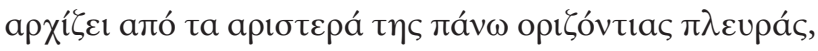

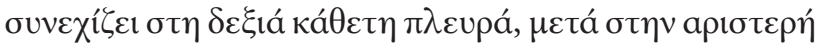

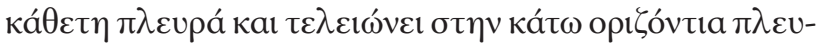

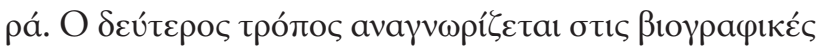

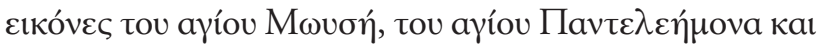

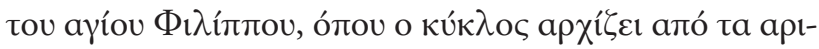

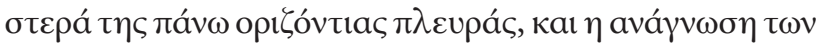

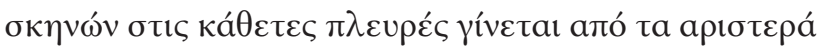

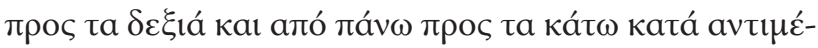
$\tau \omega \pi a \zeta \varepsilon u ́ \gamma \eta$.

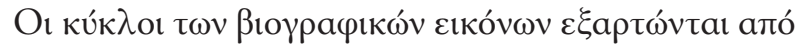

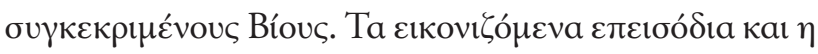

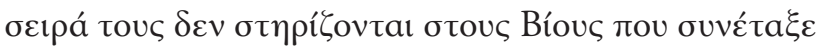

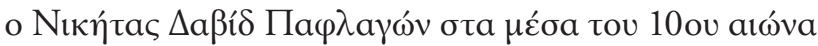

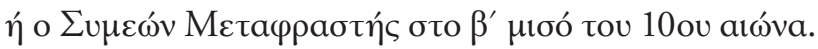

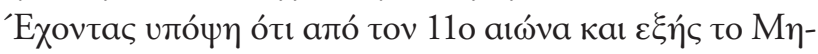

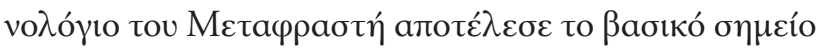
ava

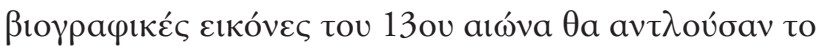
טגıкó a

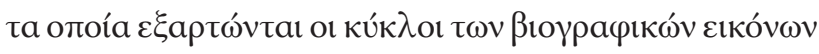

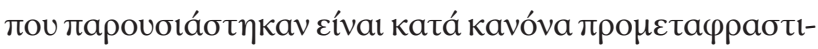

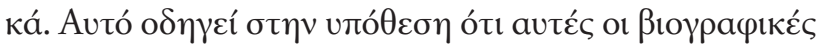

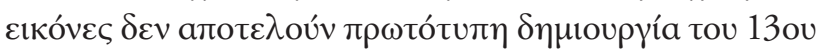

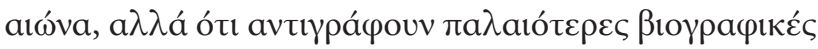

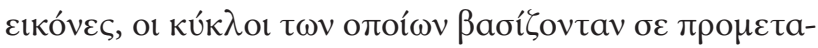
фрабтккоúc Bíous. 